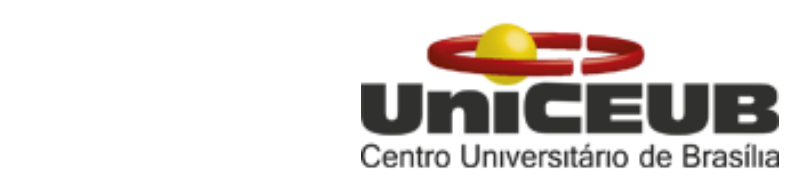

CENTRO UNIVERSITÁRIO DE BRASÍLIA - UniCEUB

PROGRAMA DE INICIAÇÃO CIENTÍFICA

LARISSA SILVA RODRIGUES NERES

RENATA DA SILVA BOITRAGO

APROVEITAMENTO dE ÁGUA CINZA PARA USO NÃO POTÁVEL EM

RESIDÊNCIAS

BRASÍLIA

2018 


\section{Unce $=$ B \\ Centro Unıversıtárıo de Brasílıa}

\section{LARISSA SILVA RODRIGUES NERES}

RENATA DA SILVA BOITRAGO

\section{APROVEITAMENTO DE ÁGUA CINZA PARA USO NÃO POTÁVEL EM RESIDÊNCIAS}

Relatório final de pesquisa de Iniciação Científica apresentado à Assessoria de Pós-Graduação e Pesquisa.

Orientação: Rogério Pinheiro Magalhães Carvalho

\section{BRASÍLIA}




\title{
APROVEITAMENTO DE ÁGUA CINZA PARA USO NÃO POTÁVEL EM RESIDÊNCIAS
}

\author{
Renata da Silva Boitrago - UniCEUB, PIC Institucional, aluno bolsista \\ renata.boitrago@sempreceub.com \\ Larissa Silva Rodrigues Neres - UniCEUB, PIC institucional, aluno voluntário \\ larissa.neres@sempreceub.com
}

Rogério Pinheiro Magalhães Carvalho - UniCEUB, professor orientador

rogerio.magalhaes@ceub.edu.br

A água é indispensável para a manutenção da vida no planeta, pois ela é parte constituinte de todos os seres vivos. No entanto, o volume de água potável disponível para consumo tem se tornado cada vez mais escasso. A reutilização de águas cinza tratadas em residências pode constituir-se em uma alternativa para garantir a sustentabilidade ambiental, de modo a reduzir a demanda por esse bem. Este trabalho teve como objetivo geral estudar um sistema experimental de reuso de águas cinza proveniente de uma máquina de lavar roupas e de um tanque, com o intuito de avaliar a qualidade da água submetida a um tratamento cujo leito filtrante foi composto por seixos, areia, carvão ativado e manta sintética, sendo realizada uma desinfecção com pastilhas de cloro, aplicando técnicas de coleta e tratamento para o uso não potável e a sua possibilidade de reuso em tempos de economia do insumo ou escassez. A primeira etapa do projeto destinou-se a implantação do sistema de tratamento. A segunda etapa consistiu nos testes para comprovar a eficiência do filtro com as diferentes camadas filtrantes. Definiu-se como variáveis de controle para avaliar a qualidade da água produzida na residência os seguintes parâmetros: Demanda Bioquímica de Oxigênio - DBO, cor verdadeira, turbidez, pH, cloro residual livre e a presença de coliformes totais e termotolerantes. Os resultados obtidos na primeira carreira de filtração, que era composta apenas por seixos de duas granulometrias, resultaram em uma coloração acentuada, contudo o resultado laboratorial não indicou a presença de organismos indicadores de patogenicidade. $\mathrm{Na}$ tentativa de melhorar a qualidade visual do efluente, adicionou-se uma camada de areia, com $5 \mathrm{~cm}$ de espessura, durante a realização da segunda carreira de filtração, e foi constatado que houve uma melhora não só do aspecto visual da água, mas também do parâmetro turbidez, havendo uma redução desse parâmetro da ordem de $17 \%$. O último material filtrante adicionado, na terceira carreira de filtração, foi o carvão ativado, cuja espessura foi de $4 \mathrm{~cm}$. Com o uso do carvão ativado, foi possível observar também que houve uma redução do odor da água, o que é perfeitamente plausível, haja vista que a literatura técnica relata que o carvão tem essa capacidade. Em geral, os resultados encontrados demonstraram que os valores de $\mathrm{pH}$, cloro residual livre e coliformes estão de acordo com as diretrizes estabelecidas pela Resolução CONAMA 357/2005 e pela Agência Americana (EPA) para águas de reuso. Para os demais parâmetros (DBO, cor e turbidez), os resultados indicaram que o tratamento proposto necessita de aperfeiçoamento, pois o efluente produzido foi enquadrado com uso restrito.

Palavras-Chave: Reuso. Água Cinza. Sistema de Tratamento. Qualidade da Água. 


\section{SUMÁRIO}

1 INTRODUÇÃO

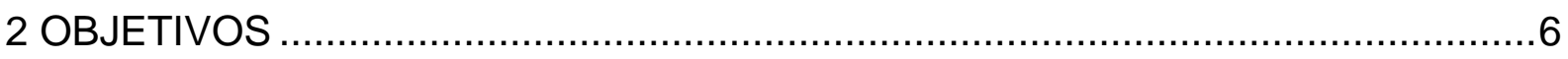

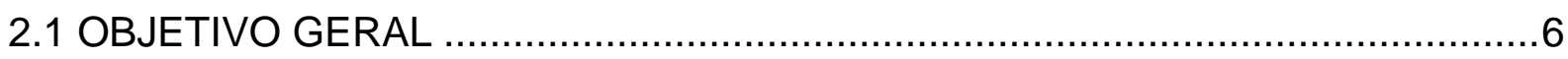

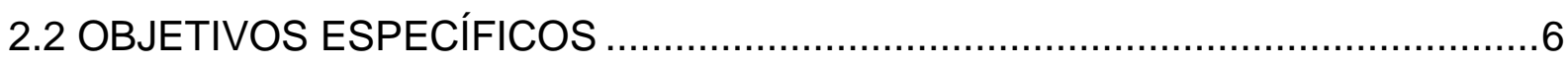

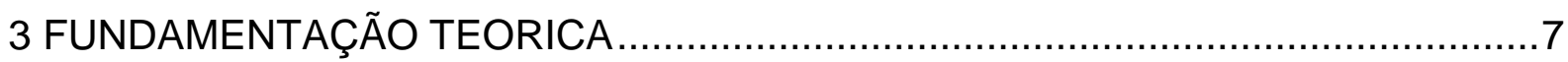

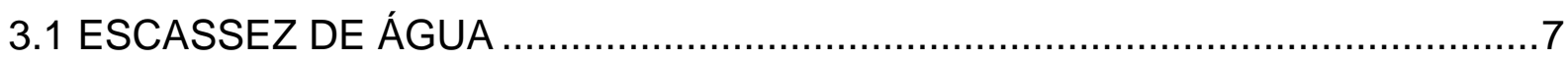

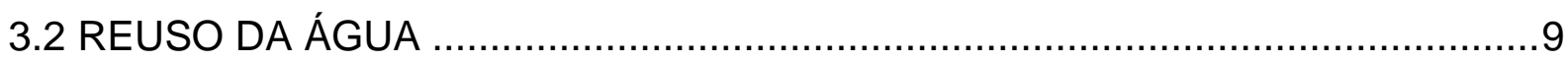

3.3 TRATAMENTO DA ÁGUA CINZA E FORMAS DE REUSO.............................11

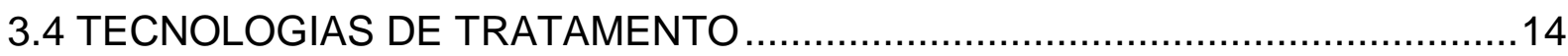

3.4.1 SISTEMAS SIMPLIFICADOS TIPO DOIS-ESTÁGIOS .................................17

3.4.2 SISTEMAS FÍSICOS E FÍSICOS-QUÍMICOS ..............................................18

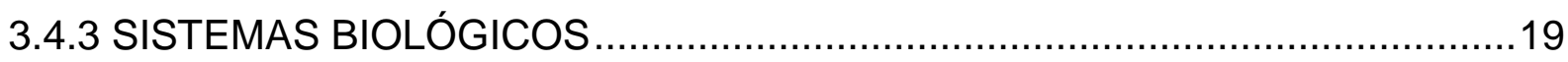

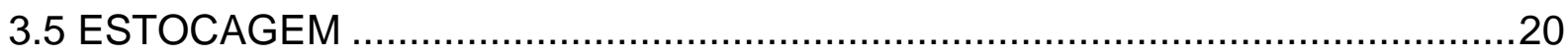

3.6 PARÂMETROS RELATIVOS A QUALIDADE DA ÁGUA .................................21

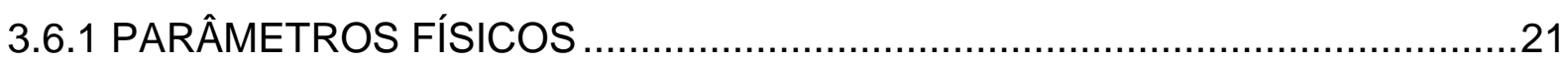

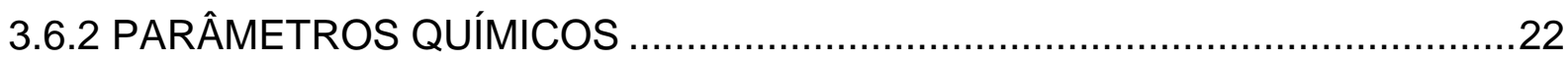

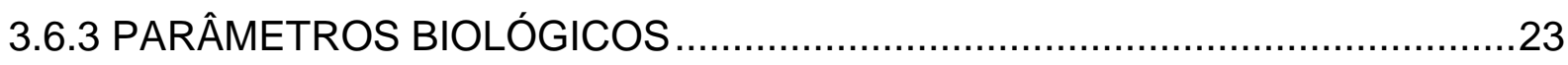

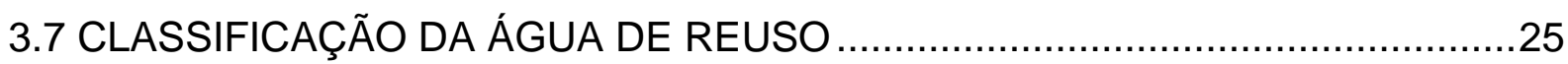

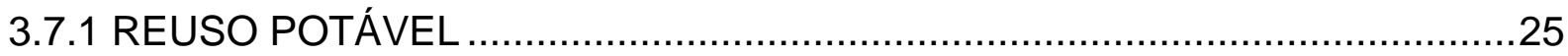

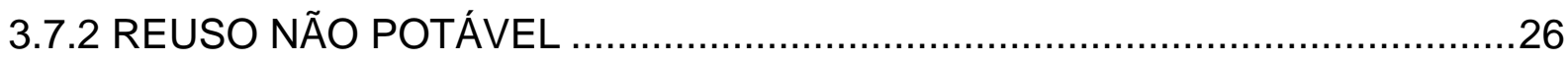

3.8 LEIS, NORMAS E PADRÕES DO REUSO DA ÁGUA NO BRASIL ...................29

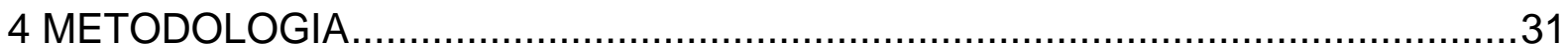

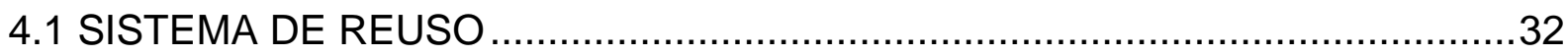

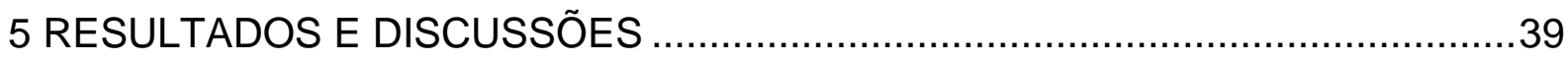

5.1 CUSTO DE IMPLANTAÇÃO DA ETA-PILOTO ……...................................

5.2 PROPOSTA DE MODELO PARA UMA UNIDADE DE TRATAMENTO PARA

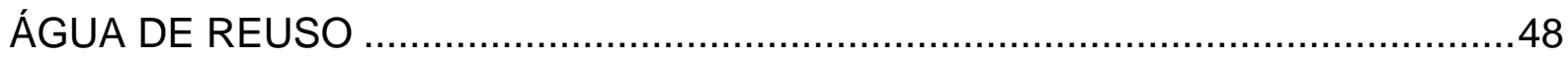

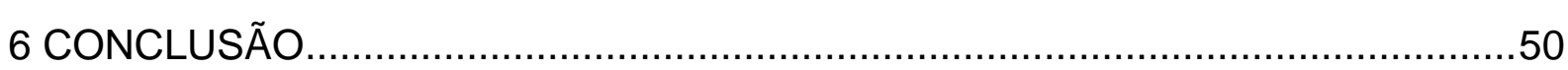

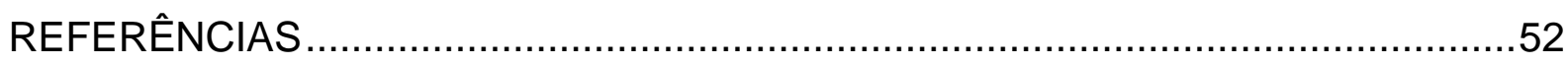

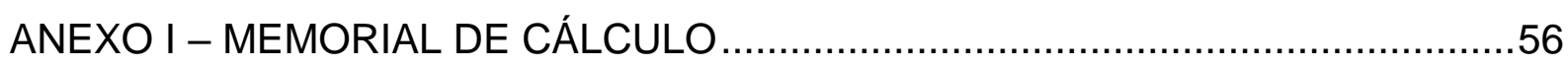

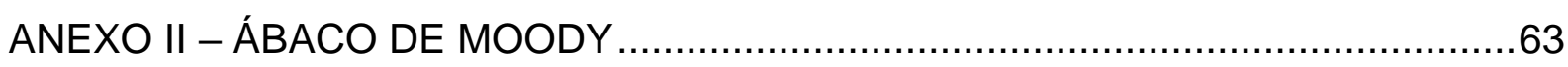

ANEXO III - TABELA PERDA DE CARGAS LOCALIZADAS .................................64 


\section{INTRODUÇÃO}

O aumento populacional, acompanhado pelas mudanças climáticas, vem contribuindo para o aumento da demanda pelos recursos hídricos. Embora a água existente seja um recurso renovável, ela tende a se deteriorar em função do seu uso indiscriminado, o que compromete, consequentemente, a quantidade de água com qualidade disponível para consumo nas diversas localidades (RAMPELOTTO, 2014).

É relevante, portanto, o desenvolvimento de tecnologias e soluções alternativas, uma vez que o aumento populacional faz com que a demanda pelos recursos hídricos aumente dia após dia. Mesmo que a água seja um recurso renovável, o uso irresponsável pode comprometer a sua disponibilidade quantitativa e qualitativa. Nesse sentido, o incentivo ao uso racional da água é uma forma de prevenir sua escassez (SELLA, 2011).

O reuso de água, quando bem planejado, tem demonstrado ser uma das alternativas mais interessantes de suprimento. Reusar água é reaproveitar a água recuperada de águas residuárias (efluentes), através da remoção ou não de parte dos resíduos por ela carreada em uso anterior, e usá-la novamente em aplicações menos exigentes que o primeiro uso (METCALF; EDDY, 2003 apud SCHULZ et al 2014).

Uma das principais fontes de consumo de água são as residenciais. Alguns países da Europa e Estados Unidos já concentram seu foco de ações nessa escala. Em áreas densamente urbanizadas, o consumo de água nas edificações pode atingir até $50 \%$ do consumo total de água potável. Uma redução significativa desse consumo (30\% a 40\%) pode ser atingido nas residências através de técnicas racionalizadoras (por exemplo, o uso de dispositivos economizadores nos aparelhos) ou através da utilização de fontes alternativas de suprimento (por exemplo, água de chuva, água do mar dessanilizada ou o reuso de águas servidas, também conhecida como água cinza) para fins menos nobres (por exemplo, lavagem de veículo, rega de jardins, descarga de vasos sanitários) (BAZZARELLA, 2005).

A busca por soluções tecnológicas que visam um melhor aproveitamento dos recursos naturais, maior conforto e economia nas construções não para de aumentar, objetivando sempre atingir o mínimo impacto e a máxima integração com o ambiente, principalmente no que se refere à preocupação com o aumento da demanda de água tratada. Nesse contexto, o reuso da água ganha a cada dia maior destaque (SELLA, 2011). 
A vantagem na utilização de águas cinza para reuso se deve ao fato de ser uma fonte pouco contaminada por atividade humana e com baixo teor de material orgânico. A água cinza representa cerca de $70 \%$ da água consumida nas residências, contento $30 \%$ do total da matéria orgânica e 9-20\% de nutrientes. Além disso, a reutilização de águas cinza in loco nas residências poderia suprir a demanda de água para vaso sanitário, jardinagem e lavagem de carro e pisos (PIDOU et al., 2007). Um estudo realizado na cidade de São Paulo-SP, em 2005, revelou que o vaso sanitário consome cerca de $29 \%$ da água potável, ao passo que águas cinzas têm potencial para substituir até $43 \%$ da água potável, contabilizando a água de banho, máquina de lavar roupas e tanque (GONÇALVES, 2006).

Portanto, este trabalho tem o escopo principal de indicar um mecanismo que possa ser utilizado em residências para o aproveitamento de águas cinza, de modo a contribuir para a redução da demanda no sistema público de abastecimento de água potável, e realizar a caracterização e avaliação da qualidade da água cinza, observando, no que couber, as normas sanitárias vigentes e as condições técnicas específicas estabelecidas pelo órgão de controle no âmbito Distrital e Nacional. 


\section{OBJETIVOS}

\subsection{OBJETIVO GERAL}

Este trabalho tem como objetivo geral estudar um sistema experimental de reuso de águas cinza residencial, com o intuito de aplicar técnicas de coleta e tratamento para o uso não potável.

\subsection{OBJETIVOS ESPECÍFICOS}

- Desenvolvimento de um projeto de reuso de águas cinza;

- Verificação dos custos de implantação do sistema de tratamento;

- Verificação preliminar da qualidade da água após tratamento;

- Propor um modelo para uma nova unidade de tratamento para água de reuso;

- Identificar os potenciais usos da água cinza para reuso;

- Realizar a análise da água de reuso da estação piloto e verificar se está de acordo com os parâmetros estabelecidos para utilização. 


\section{FUNDAMENTAÇÃO TEORICA}

Este componente do trabalho constituiu de uma extensa pesquisa bibliográfica destacando os temas de reuso da água para fins não potáveis com o foco principal para o reuso de águas cinza. A caracterização das águas cinza foi feita de acordo com a sua origem (banheiro ou lavanderia). Associado ao reuso da água, serão abordados métodos, sistemas de tratamento e etapas a partir dos critérios de qualidade que são propostos

\subsection{ESCASSEZ DE ÁGUA}

A água é indispensável para a manutenção da vida no planeta, pois ela é parte constituinte de todos os seres vivos. É através dela que se pode conceber a atmosfera, o clima, a vegetação, a agricultura e as reações celulares necessárias ao metabolismo da vida (FERREIRA, 2005).

Conforme Clarke e King (2005), a Terra dispõe de aproximadamente de 1,386 km³ de água. Contudo, tem-se que cerca de $97,4 \%$ dessa água apresenta-se espalhada por oceanos, mares, lagos salgados e aquíferos salinos, e somente uma pequena fração dessa imensa quantidade, 2,6\%, corresponde a água doce.

Assim, de acordo com a Figura 1, pode-se verificar que os 2,6\% da água doce do planeta se distribuem entre água disponível e indisponível. A primeira, cerca de $23,3 \%$, corresponde a água de subsolos, lagos, rios, plantas, animais e umidades de solo e do ar; enquanto a segunda, cerca de 76,7\%, corresponde a água aprisionada nas geleiras, neves, gelos e subsolos congelados (CLARKE E KING, 2005).

Figura 1 - Distribuição da água no planeta

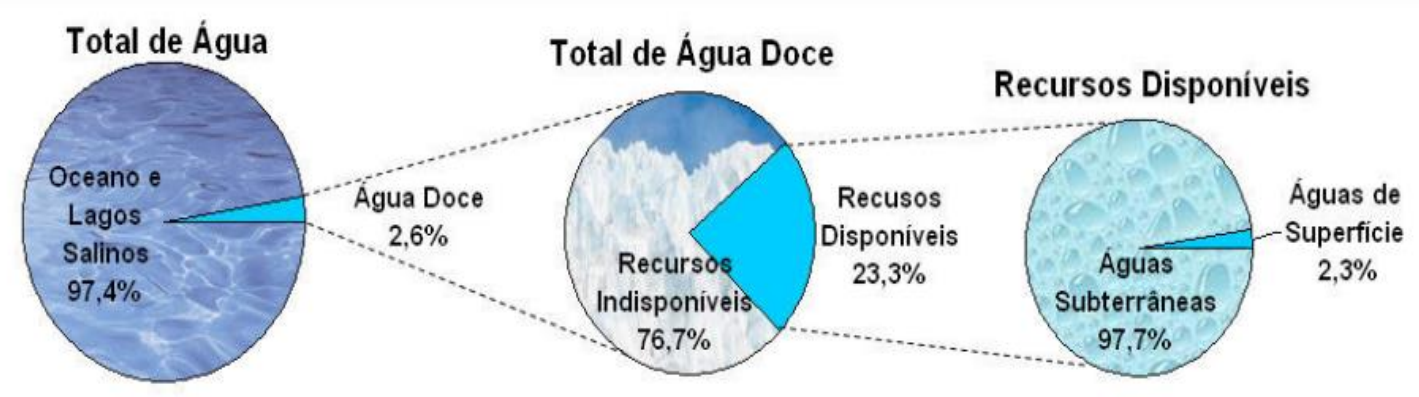

Fonte: Clarke e King, 2005.

Conforme pode ser observado na Figura 1, entre os recursos de águas disponíveis, apenas uma pequena parcela $(2,3 \%)$ se encontram sob a forma de águas de superfície, aquelas 
que são de mais fácil acesso e, por isso, mais facilmente degradadas. A outra parcela de águas disponíveis (97,7\%) apresenta-se como águas subterrâneas constituídas por lençóis freáticos e aquíferos, alguns tão complexos e heterogêneos, que tornam seu acesso mais dificultado. Exemplo desse tipo de estruturação hidrogeológica é o aquífero Guarani, que apesar de abranger cerca de 1,2 milhão de $\mathrm{km}^{2}$, espalhando-se pelo Paraguai, Uruguai, Argentina e oito estados brasileiros, contempla pontos que não é possível acessar suas águas, como ocorre na Argentina, em que o sistema aquífero apresenta-se confinado em grandes profundidades (MACHADO, 2009).

A Cidade do México é um dos lugares onde pode ser encontrado um dos exemplos mais dramáticos da exploração excessiva dos recursos hídricos. A extração de águas subterrâneas é tão intensa, que chega a exceder em $80 \%$ o potencial de recarga. Tudo isto origina uma crise definitiva, tendo em vista o fato de provocar o afundamento do solo na cidade. Estas consequências negativas serão irreversíveis (MUNDO DA ÁGUA, 2004 apud FERREIRA, 2005).

Conforme estimativas realizadas pela UNESCO (2018), cerca de $20 \%$ da população mundial não possui acesso à água potável, ressaltando, ainda, que aproximadamente $40 \%$ não têm sequer água suficiente para higiene pessoal e saneamento básico adequados. Exemplo característico é definido quando se compara a quantidade de água gasta para uma pessoa realizar suas atividades diárias. A Organização das Nações Unidas (ONU) definiu que o volume necessário para tais atividades é equivalente a 40 litros por dia, contudo um europeu utiliza em média 150 litros, enquanto um indiano consome apenas 25 litros (IDEC, 2010).

A ideia de que o Brasil é um país que tem uma grande disponibilidade hídrica é reforçada no fato de possuir, segundo Tomaz (2001), uma quantidade de água doce que corresponde a $12 \%$ do total mundial. Possui, também, grandes reservas de água em praticamente todos os Estados, excetuando-se aqueles que se localizam no semiárido nordestino.

Mesmo o Brasil sendo um país com abundância de recursos hídricos, a escassez da água é preocupante devido a demanda populacional excessiva. A primeira razão dos problemas de escassez é a má distribuição hídrica, onde algumas regiões são privilegiadas com grande quantidade de água, como a região amazônica. Outro motivo é o uso irracional da água, como o desperdício e a poluição, levando a qualidade da água a padrões inaceitáveis para o consumo humano (CUNHA, 2008). 
Diante disso, apesar de abundante, a distribuição de água é bastante desigual entre as cinco regiões do país. Segundo com Ghisi (2004), a Região Norte abrange 45\% de área territorial e possui cerca de $69 \%$ da água disponível do país, para atender a apenas $8 \%$ da população. Estes e outros dados podem ser observados no Tabela 1, que considera a população brasileira do ano 2000.

Tabela 1 - Proporção de área territorial, disponibilidade de água e população para as cinco regiões brasileira

\begin{tabular}{|c|c|c|c|}
\hline REGIÕES DO BRASIL & ÁREA TERRITORIAL (\%) & $\begin{array}{c}\text { DISPONIBILIDADE DE } \\
\text { ÁGUA (\%) }\end{array}$ & POPULAÇÃO (\%) \\
\hline Norte & 45 & 69 & 8 \\
\hline Nordeste & 18 & 3 & 28 \\
\hline Sudeste & 11 & 6 & 15 \\
\hline Sul & 7 & 6 & 7 \\
\hline Centro-Oeste & 19 & 15 & \\
\hline
\end{tabular}

Fonte: GHISI (2004).

O desequilíbrio entre a concentração de água e a população no Brasil é bastante intensa. Nas regiões onde há predominância das atividades industriais e agrícolas existem uma pequena percentagem de volume de água, verificando-se o oposto nas regiões onde essas atividades não são intensas (MAY et al., 2004).

Segundo a Associação Brasileira de Química - ABQ (2015), países com grande disponibilidade hídrica, como é o caso do Brasil, já apresentam problemas de escassez de recursos hídricos, seja por causas naturais ou pela demanda excessiva, principalmente em regiões altamente urbanizadas. Discussões e leis à parte, o fato é que a demanda por água cresce a cada ano e as reservas disponíveis não são inesgotáveis. Nesse sentido, ações devem alertar a sociedade para a importância da economia da água (uso e reuso), até o estabelecimento de políticas públicas que garantam o gerenciamento democrático, sustentável e integrado dos recursos hídricos.

\subsection{REUSO DA ÁGUA}

Em busca de tecnologias limpas, o reuso da água é uma alternativa viável tanto para indústrias como para o uso doméstico, da mesma forma é um meio de economizar os recursos hídricos, conservando aqueles já disponíveis. As iniciativas de racionalização do uso e de reuso de água se constituem em elementos fundamentais em qualquer iniciativa de conservação, 
pois atua de forma direta na disponibilidade deste recurso natural para atender o crescimento da população, para implantação de novas indústrias e na preservação e conservação do meio ambiente (OLIVEIRA; SILVA; CARNEIRO 2013).

Segundo Allen, Chistian-Smith e Palaniappan (2010), à medida em que as pressões sobre os recursos de água doce crescem em todo o mundo e que novas fontes de abastecimento se tornam cada vez mais escassas, caras ou politicamente controversas, esforços estão em andamento para identificar novas formas de atender às necessidades de água. São de destacar os esforços para reduzir a demanda de água, aumentando a eficiência do seu uso e expandindo a utilidade de fontes alternativas de água anteriormente consideradas inutilizáveis. Entre essas possíveis novas fontes de suprimento está a "água cinza".

A água cinza geralmente se refere às águas servidas, originadas em residências (ou também escolas, escritórios ou edifícios públicos), que não possui contribuição de efluentes de vasos sanitários. Também pode ser considerada como água residuária proveniente do uso de lavatórios, chuveiros, banheiros, pias de cozinha, máquina de lavar roupa e tanque (JEFFERSON et al., 1999). Alguns autores, como Nolde (1999) e Christova-Boal et al. (1996), não consideram como água cinza o efluente oriundo de cozinhas, por considerá-la altamente poluída, putrescível e com inúmeros compostos indesejáveis, como por exemplo, óleos e gorduras. A Figura 2 mostra a configuração de um determinado sistema de reuso.

Figura 2 - Sistema de reuso de água cinza

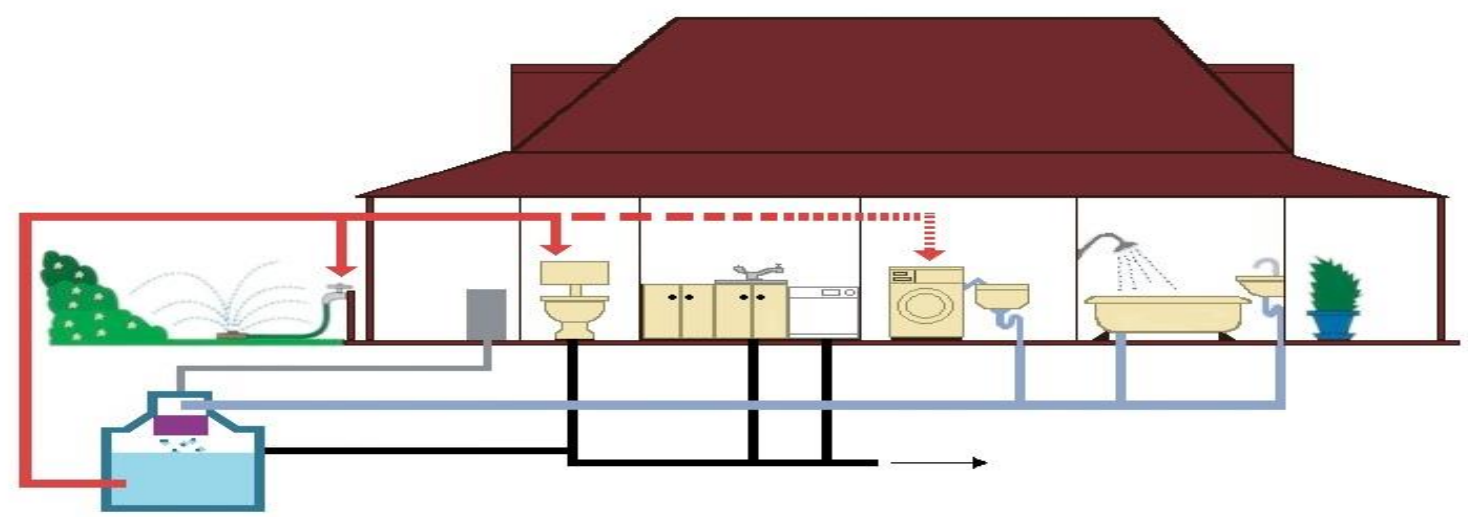

Fonte: Serpa, 2018.

As águas cinzas são divididas em duas categorias: águas cinzas claras e águas cinzas escuras. As águas cinzas claras são águas residuárias provenientes de chuveiros, de lavatórios e de máquinas de lavar roupas. Já as águas cinzas escuras incluem as águas provenientes de 
pias da cozinha e de máquinas de lavar pratos (HENZE \& LEDIN,2001 apud MAY e HESPANHOL, 2008).

As águas cinzas distinguem-se das "águas negras", visto que esta água é o efluente proveniente dos vasos sanitários, contendo basicamente fezes, urina e papel higiênico ou proveniente de dispositivos separadores de fezes e urina, tendo em sua composição grandes quantidades de matéria fecal e papel higiênico. Apresentam elevada carga orgânica e presença de sólidos em suspensão, em grande parte sedimentáveis, em elevada quantidade (GONÇALVES, 2006).

Em muitos sistemas de serviços públicos em todo o mundo, a água cinza é combinada com água negra em um único fluxo de águas residuais domésticas. No entanto, a água cinza tem a qualidade muito superior à da água negra, devido ao seu baixo nível de contaminação e maior potencial de reutilização. Quando a água cinza é reutilizada no local ou nas proximidades, ela tem o potencial de reduzir a demanda por novos suprimentos, reduzir a energia e atender a uma ampla gama de necessidades sociais e econômicas. Em particular, a reutilização de água cinza pode ajudar a reduzir a demanda por água potável de alta qualidade e dispendiosa (ALLEN; CHISTIAN-SMITH; PALANIAPPAN, 2010).

A reutilização de águas cinza tratadas em residências pode constituir-se em uma alternativa para garantir a sustentabilidade ambiental, de modo a reduzir a demanda por recurso que a cada dia torna-se mais escasso. Adicionalmente, pode contribuir para reduzir o volume de contaminantes do solo e dos corpos d'água. Em alguns casos, principalmente em edificações de grande porte, a prática do reuso apresenta-se como uma alternativa mais atrativa, em termos econômicos, do que a utilização de águas pluviais (ALVES et al., 2009).

A água cinza representa cerca de $70 \%$ da água consumida nas residências, contento $30 \%$ do total da matéria orgânica e 9-20\% de nutrientes. Além disso, a reutilização de águas cinza in loco nas residências poderia suprir a demanda de água para vaso sanitário, jardinagem e lavagem de carro e pisos (PIDOU ET AL., 2007). Um estudo realizado na cidade de São PauloSP, em 2005, revelou que o vaso sanitário consome cerca de $29 \%$ da água potável, ao passo que águas cinzas têm potencial para substituir até $43 \%$ da água potável, contabilizando a água de banho, máquina de lavar roupas e tanque (GONÇALVES, 2006).

\subsection{TRATAMENTO DA ÁGUA CINZA E FORMAS DE REUSO}

De acordo com o Serpa (2015), a água cinza passando por um tratamento adequado, pode ser utilizada em diversos pontos de uma casa ou empresa. Estes usos incluem água para 
descarga de banheiros, irrigação de plantas (que gerem, ou não, comida) e limpeza de pisos. A água cinza é uma excelente fonte de nutrientes (tais como o Fósforo e o Nitrogênio) para as plantas.

Em função de suas características físico-químicas e biológicas, as águas cinza podem ser tratadas por processos de tratamento semelhantes aos utilizados em estações de tratamento de esgoto sanitário. Entretanto, deve se atentar para o fato de que as exigências quanto à qualidade do efluente tratado são muito superiores no caso de reuso de águas cinza, sobretudo quando se trata de reuso em edificações (RAPOPORT, 2004).

A água de reuso pode ter sua qualidade dividida em classes, cada uma resumindo os critérios e restrições aplicáveis a cada da situação. Conforme os parâmetros da Resolução CONAMA № 357/2005, a utilidade da água para fins não potáveis atende as características definidas nas classes 1, 2, 3 e 4. Em termos gerais, podem ser definidas as seguintes classificações conforme o reuso:

- Classe 1 - ao abastecimento para consumo humano, após tratamento simplificado; à proteção das comunidades aquáticas; à recreação de contato primário, tais como natação, esqui aquático e mergulho; à irrigação de hortaliças que são consumidas cruas e de frutas que se desenvolvam rentes ao solo e que sejam ingeridas cruas sem remoção de película; e à proteção das comunidades aquáticas em Terras Indígenas.

- Classe 2 - ao abastecimento para consumo humano, após tratamento convencional; à proteção das comunidades aquáticas; à recreação de contato primário, tais como natação, esqui aquático e mergulho; à irrigação de hortaliças, plantas frutíferas e de parques, jardins, campos de esporte e lazer, com os quais o público possa vir a ter contato direto; e à aquicultura e à atividade de pesca.

- Classe 3 - ao abastecimento para consumo humano, após tratamento convencional ou avançado; à irrigação de culturas arbóreas, cerealíferas e forrageiras; à pesca amadora; à recreação de contato secundário; à dessedentação de animais.

- Classe 4 - à navegação; e à harmonia paisagística.

A Tabela 2 mostra as classes das águas de reuso com os respectivos padrões de qualidade, conforme estabelecido na Resolução CONAMA № 357/2005. 
Tabela 2 - Classes e Parâmetros para água de reuso

\begin{tabular}{|c|c|c|c|c|c|c|c|}
\hline \multirow[b]{2}{*}{ Classes } & \multicolumn{7}{|c|}{ Parâmetro } \\
\hline & $\begin{array}{c}\text { Turbidez } \\
\text { (UNT) }\end{array}$ & $\begin{array}{c}\mathrm{DBO}_{5} \\
(\mathrm{mg} / \mathrm{l} \\
\mathrm{O}_{2)}\end{array}$ & $\begin{array}{c}\text { Cor } \\
\text { Verdadeira } \\
\text { (mg Pt/l) }\end{array}$ & $\mathrm{pH}$ & $\begin{array}{c}\text { Coliformes } \\
\text { Termot. } \\
\text { (NMP/100ml) }\end{array}$ & $\begin{array}{c}\text { Coliforme } \\
\text { Total } \\
\text { (NMP/100ml) }\end{array}$ & $\begin{array}{c}\text { Cloro } \\
\text { Residual } \\
\text { Total } \\
\text { (mg/L) }\end{array}$ \\
\hline 1 & $\leq 40$ & $\leq 3$ & $\begin{array}{c}\text { Natural ao } \\
\text { corpo } \\
\text { d'água }\end{array}$ & 6 a 9 & $\leq 200$ & $\leq 1.000$ & $\leq 0,01$ \\
\hline 2 & $\leq 100$ & $\leq 5$ & $\leq 75$ & 6 a 9 & $\leq 1.000$ & $\leq 5.000$ & $\leq 0,01$ \\
\hline 3 & $\leq 100$ & $\leq 10$ & $\leq 75$ & 6 a 9 & $\leq 4.000^{*}$ & $\leq 20.000$ & NE \\
\hline 4 & NE & NE & NE & 6 a 9 & NE & NE & NE \\
\hline \multicolumn{8}{|c|}{$\begin{array}{l}\text { Legenda: } \\
\text { NE - Não Especificado } \\
\text { *Para o uso de recreação de contato secundário não deverá ser excedido um limite de } 2500 \\
\text { coliformes termotolerantes; para dessedentação de animais criados confinados não deverá ser } \\
\text { excedido o limite de } 1000 \text {. }\end{array}$} \\
\hline
\end{tabular}

Fonte: Resolução CONAMA № 357/2005.

Para Rabêlo (2011), tornam-se necessários estudos que mostrem os reais parâmetros a serem adotados para cada tipo de reuso, fazendo com que esta prática possa ser adotada. Baseando-se em resultados mais realísticos do que os índices atuais divulgados, levando em consideração, principalmente, a questão da saúde pública.

Ainda segundo Rabêlo (2011) a qualidade da água cinza vai depender das diversas atividades domésticas realizadas, sendo que os componentes presentes variam de residência a residência, onde o estilo de vida, costumes, instalações e a quantidade de produtos químicos utilizados irão influenciar.

Para Jefferson et al. (1999), a água cinza é geralmente originada pelo uso de sabão ou de outros produtos para lavagem do corpo, de roupas ou de limpeza em geral. Ela varia em qualidade de acordo com a localidade e nível de ocupação da residência, faixa etária, estilo de vida, classe social e costumes dos moradores e com o tipo de fonte de água que está sendo utilizado (lavatório, chuveiro, máquina de lavar, etc.), como relata também Nswhealth (2000) e Nolde (1999). Outros fatores que, segundo Eriksson et al. (2002), também contribuem para 
as características da água cinza são: a qualidade da água de abastecimento e o tipo de rede de distribuição, tanto da água de abastecimento quanto da água de reuso.

A grande vantagem da utilização da água de reuso é a de preservar a água potável, reservando-a exclusivamente para o atendimento das necessidades que exijam a sua potabilidade para o abastecimento humano. Além disso, há diminuição da demanda sob os mananciais de água pura devido à substituição da fonte, ou seja, a substituição de uma água de boa qualidade por outra inferior, porém que contenha qualidade requerida para o destino traçado para ela. Outra vantagem relevante do reuso é a eliminação de descarga de esgotos nas águas superficiais, já que há um tratamento na água e os produtos resultantes do processo são destinados a locais adequados. Também em locais onde o estágio avançado de falta d'água é muito grande, a solução de reuso pode ser a melhor alternativa (FIORI et al., 2006).

\subsection{TECNOLOGIAS DE TRATAMENTO}

A análise das características do efluente, conjuntamente com os requisitos de qualidade requeridos para a aplicação de reuso desejada, geralmente define o tipo de tratamento a ser adotado (BAZZARELLA, 2005).

Em se tratando de reuso de água, devido à grande variabilidade tanto da fonte quanto da própria finalidade a que se destina o efluente tratado, ou o tipo de reuso pretendido, uma gama de sistemas ou sequencias de processos são possíveis de serem concebidos (MANCUSO E SANTOS, 2003). Os processos desenvolvidos variam desde sistemas simples em residências até séries de tratamentos avançados para reuso em larga escala (JEFFERSON et al., 1999).

Os efluentes que terão como destino algum reuso, devem passar por um tratamento, para que possam atender às expectativas dos usuários e, principalmente, para que não comprometam a saúde desses. Visto isso, alternativas de tratamento devem ser estudadas. Uma associação de etapas de tratamento de águas cinza para reutilização em vasos sanitários é apresentada (BRASIL et al., 2005):

a) primeiramente deve passar por um dos dois tratamentos abaixo:

- $\quad$ sistema físico-químico: coagulação, floculação e decantação ou flotação;

- $\quad$ sistema aeróbio de tratamento biológico de lodos ativados;

b) sistema físico: sedimentação e filtração simples através de decantador e filtro de areia;

c) processo de desinfecção;

d) por fim, caso seja necessário, executar a correção do pH. 
Para Allen, Chistian-Smith e Palaniappan (2010) os sistemas de tratamento físico e químico utilizam principalmente a desinfecção e a filtração para remover os contaminantes, enquanto o tratamento biológico utiliza biorreatores de aeração e membrana. O Tabela 3 fornece uma lista de tecnologias comuns de tratamento de água cinza e algumas de suas respectivas vantagens e desvantagens. 
Tabela 3 - Tecnologias comuns para tratamento de águas cinza

\begin{tabular}{|c|c|c|c|}
\hline $\begin{array}{l}\text { Tratamento } \\
\text { Tecnológico }\end{array}$ & Descrição & Vantagens & Desvantagens \\
\hline Desinfecção & $\begin{array}{c}\text { Cloro, ozônio ou luz ultravioleta podem ser usados } \\
\text { para desinfetar a água cinza. }\end{array}$ & $\begin{array}{l}\text { Altamente eficaz em eliminar bactérias se } \\
\text { adequadamente projetado e operado, baixa } \\
\text { habilidade do operador requerido. }\end{array}$ & $\begin{array}{l}\text { Cloro e ozônio podem formar subprodutos } \\
\text { tóxicos, ozônio e ultravioleta podem ser } \\
\text { afetados negativamente por variações no } \\
\text { conteúdo orgânico de água cinza. }\end{array}$ \\
\hline $\begin{array}{l}\text { Filtro de Carvão } \\
\quad \text { Ativado }\end{array}$ & $\begin{array}{l}\text { O carvão ativado possui minúsculos poros entre os } \\
\text { átomos de carbono. Isso resulta em alta } \\
\text { porosidade superficial com áreas de } 300-2.000 \\
\text { metros quadrados por grama. Estes filtros são } \\
\text { assim amplamente utilizados para absorver o } \\
\text { odor, a cor e substâncias de gases ou líquidos. }\end{array}$ & $\begin{array}{l}\text { Operação simples, carvão ativado é } \\
\text { particularmente bom em matéria orgânica e } \\
\text { produtos químicos, bem como compostos } \\
\text { inorgânicos como cloro. }\end{array}$ & $\begin{array}{l}\text { Alto custo de capital, muitos outros produtos } \\
\text { químicos não são atraídos pelo carbono - Sódio, } \\
\text { nitratos, etc. Isso significa que um filtro de } \\
\text { carvão ativado só irá remover certas impurezas. } \\
\text { Isso também significa que, uma vez que todos } \\
\text { os locais de ligação estão cheios, o carvão } \\
\text { ativado do filtro deixa de funcionar. }\end{array}$ \\
\hline Filtro de Areia & $\begin{array}{l}\text { Leitos de areia ou em alguns casos cascas grossas } \\
\text { ou palha que prendem e absorvem contaminantes } \\
\text { da água que flui através deste. }\end{array}$ & $\begin{array}{l}\text { Operação simples, baixa manutenção, baixos } \\
\text { custos de operação. }\end{array}$ & $\begin{array}{l}\text { Alto custo de capital, reduz patógenos, mas não } \\
\text { elimina eles, sujeitos a entupimento se } \\
\text { sobrecarregado. }\end{array}$ \\
\hline $\begin{array}{l}\text { Tratamento Biológico } \\
\text { Aeróbico }\end{array}$ & $\begin{array}{c}\text { O ar é inserido para transferir oxigênio do ar para } \\
\text { a água cinza. Bactérias presentes consomem o } \\
\text { oxigênio dissolvido e digerem os contaminantes } \\
\text { orgânicos. }\end{array}$ & $\begin{array}{l}\text { Alto grau de flexibilidade de operações para } \\
\text { acomodar a água cinza de qualidades e } \\
\text { quantidades variadas e permite tratamento da } \\
\text { água a ser armazenada. }\end{array}$ & $\begin{array}{l}\text { Alto custo de capital, alto custo operacional, } \\
\text { complexidade operacional, não remove todos } \\
\text { os patógenos. }\end{array}$ \\
\hline $\begin{array}{l}\text { Biorreator de } \\
\text { membrana }\end{array}$ & $\begin{array}{l}\text { Usa tratamento biológico aeróbico e filtração } \\
\text { juntos para induzir a eliminação de contaminantes } \\
\text { orgânicos de todos os patógenos. }\end{array}$ & $\begin{array}{c}\text { Altamente eficaz, se projetado e operado } \\
\text { corretamente, alto grau de flexibilidade de } \\
\text { operações para acomodar a água cinza de } \\
\text { qualidade variada, permite o tratamento da água } \\
\text { a ser armazenada. }\end{array}$ & $\begin{array}{l}\text { Alto custo de capital, alto custo operacional, } \\
\text { requisitos operacionais complexos. }\end{array}$ \\
\hline
\end{tabular}

Fonte: Allen, Chistian-Smith e Palaniappan, 2010 
Segundo Allen, Chistian-Smith e Palaniappan (2010), muitos sistemas básicos de tratamento e armazenamento de água cinza também incorporam filtros de carvão ativado e/ou argila e desinfecção (por exemplo, cloração, purificação com radiação ultravioleta).

De acordo com a literatura técnica pesquisada, há vários tipos de tecnologias de tratamento de águas cinza, dentre as quais pode-se destacar as tecnologias mostrados a seguir.

\subsubsection{SISTEMAS SIMPLIFICADOS TIPO DOIS-ESTÁGIOS}

A filtração grosseira seguida de desinfecção é uma tecnologia comumente utilizada no Reino Unido para reuso doméstico, e várias empresas fabricam sistemas de tratamento de reuso que se baseiam nesse processo de dois estágios (two-stage process). Segundo Jefferson et al. (1999), o processo emprega um curto período de detenção hidráulica. Assim a natureza química da água cinza permanece inalterada e apenas um mínimo tratamento é requerido. A desinfecção pode ser feita utilizando tanto cloro como bromo, sendo eles dispersos na forma de pastilha que se dissolvem lentamente ou através de dosagem de solução líquida. Entretanto, concentração de matéria orgânica elevada limita a eficiência da desinfecção química, pois dificulta a difusão do desinfetante, aumenta a demanda do agente desinfetante e, no caso do cloro, pode gerar subprodutos como cloraminas e trihalometanos.

De acordo com Hill et al. (2003), o monitoramento de um sistema foi implantado por uma empresa britânica em cinco novas residências em Aylesbury (Inglaterra), utilizando o bromo como desinfetante. Este monitoramento mostrou uma concentração de $\mathrm{DBO}_{5}$ remanescente relativamente alta $(22-87 \mathrm{mg} / \mathrm{L})$ e apresentou alguns problemas operacionais, como o entupimento da tubulação de entrada do filtro, falha na bomba e insuficiência na desinfecção. A Figura 3 mostra o sistema implantado por Hill et al. (2003). 
Figura 3 - Sistema de reuso de água cinza utilizando o processo de dois-estágios

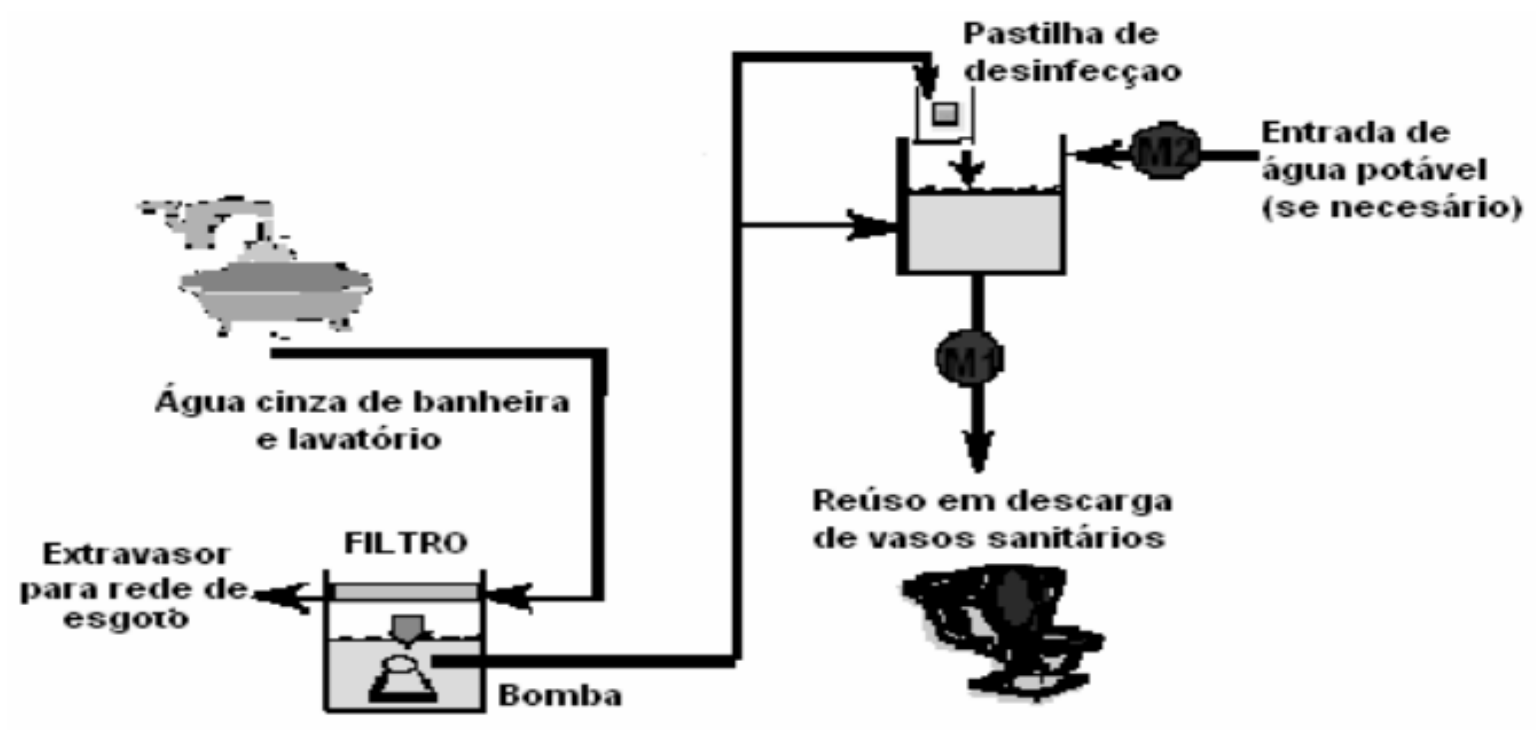

Fonte: HILL et al. (2003).

Um outro sistema de reuso implantado em um apart-hotel, localizado na llha de Mallorca (Espanha), utilizou processos de sedimentação, filtração (filtro de tela de nylon) e desinfecção (hipoclorito de sódio). Resultado satisfatório foram obtidos, através do controle adequado das condições operacionais (período de estocagem inferior a 48 horas e concentração de cloro $\geq 1 \mathrm{mg} / \mathrm{L}$ nas descargas dos toaletes). A qualidade da água de reuso (turbidez 16,5 NTU e SST 18,6 mg/L) foi bem aceita pelos hospedes do hotel, embora alguns parâmetros estivessem aquém dos padrões estabelecidos para água potável (MARCH et al., 2004).

\subsubsection{SISTEMAS FÍSICOS E FÍSICOS-QUÍMICOS}

Os processos físicos desenvolvidos para o tratamento de águas cinza correspondem principalmente à filtração com leitos de areia e processos utilizando membranas, sendo que estes últimos geralmente são precedidos de um pré-tratamento apropriado (BAZZARELLA, 2005).

A remoção de sólidos suspensos da água cinza é essencial tanto para irrigação de jardins quanto para descargas de vasos sanitários. Segundo Christova-Boal at al. (1996), a utilização de filtros pode proporcionar qualidade aceitável para esse tipo de reuso. Em alguns locais experimentais a remoção do material suspenso foi alcançada através de um sistema de filtros com três estágio (CHRISTOVA-BOAL et al., 1996): pré-filtração (remoção de sólidos 
grosseiros do efluente de lavandeira, chuveiro e banheiro), filtro de peneira (coleta principalmente de cabelo, partículas de sabão, fibra de tecidos) e filtro fino (retenção dos precipitados e do material sedimentado). Os filtros utilizados nesse mesmo experimento necessitam de limpezas periódicas com duração de 15 a 20 min, uma ou duas vezes na semana, dependendo das atividades dentro das residências. Os resíduos eram dispostos na rede de esgoto ou em latas de lixo.

Os sistemas de membranas oferecem uma barreira permanente para as partículas suspensas de dimensões superiores ao material da membrana, que podem variar de 0,5 $\mu \mathrm{m}$, para membranas de microfiltração (MF), até as dimensões moleculares utilizadas para osmose reversa. Apesar dos sistemas de membranas gerarem efluentes com baixíssima turbidez e densidade de coliformes abaixo do limite de detecção, eles apresentam a desvantagem de requererem elevadas demandas de energia (JEFFERSON et al., 1999).

\subsubsection{SISTEMAS BIOLÓGICOS}

O tratamento biológico de água cinza é requerido para remover o material biodegradável e é indicado especialmente para sistemas de reuso que possuem grandes redes de distribuição. No Japão, processos com biorreatores de membranas (do inglês MBR) têm sido muito empregados em sistemas de reuso de água em edifícios residenciais e comerciais (KISHINO et al., 1996). Esses processos de MBR combinam reatores de lodo ativado com membranas de microfiltração.

Um edifício na universidade de Kalmar, na Suécia, com capacidade para 500 alunos, foi equipado com sistema reuso de água cinza (GUNTHER, 2000). O tratamento utilizado era composto por sistemas de lagoas e wetllands, denominados de wetparks (parque molhado) (ver Figura 4). A água cinza gerada no prédio, originada da lavagem de mão e de pratos, era disposta nas raízes da vegetação plantada e armazenada em uma lagoa até atingir a outra margem. Esse processo repetia-se por três vezes para se conseguir uma grande redução de bactérias patogênicas, DBO e nutriente (Tabela 4). Após a última lagoa, a água seguia para um filtro de areia e era coletada em um reservatório. O tempo de detenção desse sistema era bastante elevado devido às baixas de temperaturas durante o inverno. De acordo com Gunther (2000), os wetparks, além de proporcionarem o tratamento da água cinza através de wetllands construídas, funcionavam também como parques para fins recreacionais. 
Figura 4 - Sistema de Wetpark para tratamento de água cinza

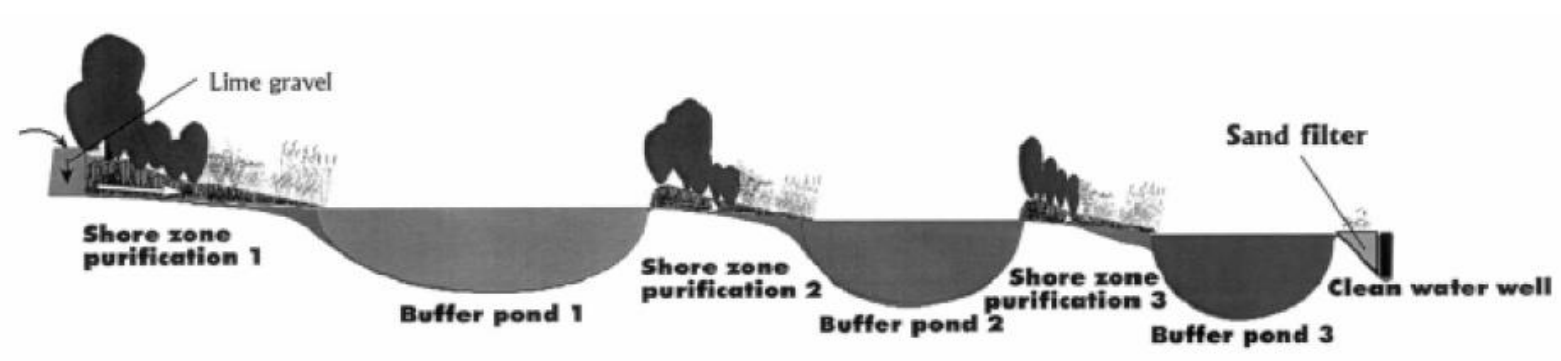

Fonte: Gunther (2000).

Tabela 4 - Resultados obtidos no sistema wetpark para tratamento de água cinza

\begin{tabular}{|c|c|c|c|c|c|}
\hline Amostras & $\begin{array}{c}\mathbf{D B O}_{\mathbf{5}} \\
\text { (mg/L) }\end{array}$ & $\begin{array}{c}\text { Nitrogênio } \\
\text { (mg/L) }\end{array}$ & $\begin{array}{c}\text { Fósforo } \\
\text { (mg/L) }\end{array}$ & $\begin{array}{c}\text { Coliformes } \\
\text { termotolerantes } \\
\text { (cfu/100mL) }\end{array}$ & $\begin{array}{c}\text { Entreptococos } \\
\text { fecais } \\
\text { (cfu/100mL) }\end{array}$ \\
\hline $\begin{array}{c}\text { Água cinza } \\
\text { bruta }\end{array}$ & 47 & 3,72 & 3,73 & $9,4 \times 10^{4}$ & $3,6 \times 10^{4}$ \\
\hline Pond 1 & 0,5 & 0,975 & 0,372 & $2,5 \times 10$ & $3,61 \times 10^{2}$ \\
\hline Pond 2 & 0 & - & - & $9,6 \times 10$ & $4,32 \times 10^{2}$ \\
\hline Pond 3 & 0,8 & 1,9 & 0,02 & $1,1 \times 10$ & $1,5 \times 10$ \\
\hline $\begin{array}{c}\text { Reservatório } \\
\text { Final }\end{array}$ & 0 & 1,618 & 0,022 & $1,72 \times 10^{2}$ & $4,3 \times 10$ \\
\hline
\end{tabular}

Fonte: Adaptado de Gunther (2000).

Para o presente trabalho, será abordado uma tecnologia que se resume em um sistema de filtração constituído de areia, seixo e carvão ativado que, de maneira geral, está mais próximo do trabalho realizado por Hill et al. (2003). Os aspectos construtivos e operacionais da unidade de tratamento serão melhor abordados no item metodologia.

\subsection{ESTOCAGEM}

A estocagem é um importante elemento em todos os sistemas de reuso de água cinza e ela se faz necessária em algum ponto desse sistema, seja ela antes do tratamento ou depois dele. Segundo Dixon et al. (1999), se a água cinza for escoada antes do tratamento, existe a vantagem de alguns sólidos primários ficarem retidos antes de chegarem ao tratamento, entretanto, há o risco da geração de odores e do crescimento de microrganismos. A água cinza quando estocada na sua forma bruta passa por significantes mudanças de qualidade. Dixon et 
al. (1999) propuseram, hipoteticamente, quatro principais processos que puderam governar essas mudanças. A sedimentação das partículas suspensas e a perda de oxigênio dissolvido (provavelmente causado pelo crescimento de biomassa aeróbia) são dominantes nas primeiras horas de estocagem. As outras dois processos-chaves são a reaeração do oxigênio dissolvido na superfície da água (colmandado pela variação de temperatura) e a liberação da DQO solúvel devido à degradação anaeróbia do material particulado sedimentado (teoria baseada principalmente pela observação do aumento da DQO, após alguns dias de estocagem e pela produção de maus odores, confirmando a anaerobiose).

Para Rampelotto (2014) estudos devem abordar alternativas de sistema de aproveitamento e reuso de água para determinar a quantidade de água gerada (oferta) e pelas fontes escolhidas e a quantidade de agua destinada às atividades fim (demanda). Tomandose por base estes valores, devem ser dimensionados os equipamentos, os volumes de reservas necessários, os possíveis volumes complementares de água e escolhidas as tecnologias de tratamentos a serem empregadas. Com base nas alternativas de sistema geradas, determinam-se quais as de maior eficiência, tanto no aspecto técnico quanto econômico.

\subsection{PARÂMETROS RELATIVOS A QUALIDADE DA ÁGUA}

De acordo com Rapoport (2004), parâmetros físicos, químicos e biológicos tem que ser analisados para avaliar a qualidade da água. A seguir, baseado nas referências dessa autora, são mostrados resumidamente, alguns dos principais parâmetros.

\subsubsection{PARÂMETROS FÍSICOS}

- Sólidos totais: Toda a matéria que permanece como resíduo após evaporação à temperatura de $103^{\circ} \mathrm{C}$ a $105^{\circ} \mathrm{C}$. O material que possui significativa pressão de vapor nesta temperatura é perdido durante a evaporação e não é definido como sólido.

- Temperatura: A temperatura das águas residuais é um parâmetro de grande importância devido a seu efeito na vida aquática, podendo causar o decaimento de oxigênio na água devido ao aumento do metabolismo dos seres vivos e florescimento de fungos e plantas aquáticas indesejáveis.

- Cor: Provocada por corantes orgânicos e inorgânicos. 
- Odor: provocado pela decomposição da matéria orgânica e a presença de compostos de enxofre.

- Turbidez: Presença de partículas em suspensão que interferem na passagem da luz através da água. É esteticamente desagradável e o material particulado pode impedir a ação de alguns agentes desinfetantes como o Ultravioleta (UV) e principalmente a reação com o cloro, desinfetante mais utilizado no país.

\subsubsection{PARÂMETROS QUÍMICOS}

- DBO (Demanda Bioquímica de Oxigênio): É o parâmetro mais usual de medição de poluição orgânica e determina a quantidade aproximada de oxigênio que será necessária para oxidar biologicamente a matéria orgânica presente. O período de incubação é usualmente de cinco dias a $20^{\circ} \mathrm{C}$. A estabilização biológica das substâncias orgânicas em uma água contendo oxigênio dissolvido realiza-se em duas fases. Na primeira são atacados os compostos carbonáceos e na segunda a amônia.

- DQO (Demanda Química de Oxigênio): É o parâmetro utilizado para medir tanto a matéria orgânica degradável como a não biodegradável (inseticidas, detergentes). Na demanda química de oxigênio a matéria orgânica que pode ser oxidada é medida utilizando-se dicromato de potássio ou qualquer outro oxidante forte. A DQO geralmente é maior do que a DBO em um despejo, em virtude da maior facilidade com que grande número de compostos pode ser oxidado por via química.

- pH (Potencial Hidrogeniônico): A concentração hidrogeniônica determina a condição de alcalinidade, neutralidade e acidez e interfere na coagulação química, no controle da corrosão e desinfecção. Em processos de tratamento biológico, físico ou químicos de águas residuais, interfere nas velocidades de tratamento e nas eficiências de consumo de substrato pelos micro-organismos.

- Metais pesados: tais como cromo, chumbo, zinco e mercúrio. Não tem função biológica conhecida e são geralmente tóxicos a uma grande variedade de organismos.

- OD (Oxigênio Dissolvido): Representa a quantidade de oxigênio dissolvido na água. Provém do contato da água com a atmosfera e da produção por organismos fotossintéticos. Durante a estabilização da matéria orgânica, as bactérias utilizam o OD para respiração causando consequentemente sua redução no meio. Caso o oxigênio seja totalmente 
consumido surgem condições anaeróbias que ocasionam odores desagradáveis. A solubilidade do Oxigênio varia com a temperatura e pressão.

- Nitrogênio: Pode ser encontrado sob várias formas e estados de oxidação no meio aquático entre elas: forma molecular $\left(\mathrm{N}_{2}\right)$, Amônia $\left(\mathrm{NH}_{3}\right)$, Nitrito $\left(\mathrm{NO}_{2}\right)$, Nitrato $\left(\mathrm{NO}_{3}\right)$ e íon amônio $\left(\mathrm{NH}_{4}\right)$. Entre as formas que servem como fontes de nitrogênio para os produtores primários está o nitrato e o íon amônio. Altas concentrações do íon amônio podem ter grandes implicações na dinâmica do oxigênio dissolvido do meio já que para oxidar 1,0 mg do íon amônio são necessários cerca de 4,3 mg de oxigênio.

\subsubsection{PARÂMETROS BIOLÓGICOS}

- Vírus: Multiplicam-se apenas no interior das células animais e vegetais. São agentes causadores de diversas enfermidades. Possuem de 10 a 300 micrometros e podem atravessar filtros que retém a maioria das bactérias. A maioria relacionada à água é eliminada, pois o meio é agressivo e não próprio para a multiplicação. Segundo d'Aguila (1996) e Ferreira (1999), a probabilidade de presença de vírus em água se dá pela presença da hepatite vírus A, de alguns causadores da meningite e remotamente pelos poliovirus.

- Bactérias: são organismos procariotas, unicelulares que se reproduzem por divisão binária simples. Uma fração importante da população de bactérias presente no esgoto sanitário faz parte da microbiota do trato intestinal dos seres humanos. Dentre elas, destaca-se o grupo das bactérias coliformes fecais, recentemente denominadas termotolerantes, selecionadas por suas características, como organismos indicadores de contaminação de águas de modo geral. Normalmente, os organismos indicadores não são causadores de doenças, porém, estão associadas às prováveis presenças de organismos patogênicos de origem fecal na água.

- Enterococos: bactérias do grupo dos estreptococos fecais, pertencentes ao gênero Enterococcus (previamente considerado estreptococos do grupo D), o qual se caracteriza pela alta tolerância às condições adversas de crescimento, tais como: capacidade de crescer na presença de $6,5 \%$ de cloreto de sódio, a pH 9,6 e nas temperaturas de $10^{\circ}$ e $45^{\circ} \mathrm{C}$. A maioria das espécies de Enterococcus é de origem fecal humana, embora possam ser isolados de fezes de animais.

- Coliformes totais (bactérias do grupo coliforme) - bacilos gram-negativos, aeróbios ou anaeróbios facultativos, não formadores de esporos, oxidase-negativos, capazes de 
desenvolver na presença de sais biliares ou agentes tensoativos que fermentam a lactose com produção de ácido, gás e aldeído a 35,0 \pm 0,5 ํ em 24-48 horas, e que podem apresentar atividade da enzima ß-galactosidase. A maioria das bactérias do grupo coliforme pertence aos gêneros Escherichia, Citrobacter, Klebsiella e Enterobacter, embora vários outros gêneros e espécies pertençam ao grupo;

- Coliformes termotolerantes - subgrupo das bactérias do grupo coliforme que fermentam

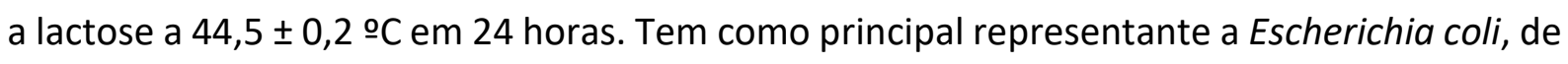
origem exclusivamente fecal; bactérias pertencentes ao grupo dos coliformes totais caracterizadas pela presença da enzima ß-galactosidade e pela capacidade de fermentar a lactose com produção de gás em 24 horas à temperatura de $44-45^{\circ} \mathrm{C}$ em meios contendo sais biliares ou outros agentes tenso-ativos com propriedades inibidoras semelhantes. Além de presentes em fezes humanas e de animais podem, também, ser encontradas em solos, plantas ou quaisquer efluentes contendo matéria orgânica.

- Escherichia coli - bactéria pertencente à família Enterobacteriaceae, caracterizada pela presença das enzimas ß-galactosidade e ß-glicuronidase. Cresce em meio complexo a $44-45^{\circ} \mathrm{C}$, fermenta lactose e manitol com produção de ácido e gás e produz indol a partir do aminoácido triptofano. É considerado o mais específico indicador de contaminação fecal recente e de eventual presença de organismos patogênicos. Também é abundante em fezes humanas e de animais, tendo, somente, sido encontrada em esgotos, efluentes, águas naturais e solos que tenham recebido contaminação fecal recente.

- Protozoários: Organismos unicelulares, eucariotas. O ciclo de vida dos protozoários relacionados ao esgoto é composto de um estágio vegetativo e um estágio inativo que permite ao organismo sobreviver em condições adversas. Os protozoários patogênicos aos seres humanos mais comuns são Entamoeba hystolitica, Giárdia lamblia, e mais recentemente atenção vem sendo dada ao Cryptosporidium. Os cistos apresentam sobrevivência moderada no meio ambiente, porém são bem mais resistentes que as bactérias e os vírus a ação dos desinfetantes. Por outro lado, apresenta tamanho (04-60 $\lambda \mathrm{m}$ ) e densidades que favorecem sua remoção por sedimentação e filtração.

- Helmintos: Organismos eucariotas, pluricelulares. Os helmintos patogênicos aos seres humanos pertencem a dois filos Platelmintos que são vermes de corpo achatado (Classe trematoda e Classe cestoda) e Asquelmintos, vermes de corpo cilíndrico (Classe Nematoda). Apresentam-se sob a forma de ovos ou larvas e são visíveis ao microscópio ótico. Os ovos 
atingem de 20 a $50 \lambda \mathrm{m}$. Os ovos são resistentes no meio ambiente e à ação da maioria dos desinfetantes. Sua remoção é preferencialmente realizada em processos de separação sólido/líquido (filtração e sedimentação), devido ao tamanho e a densidade de ovos e larvas.

\subsection{CLASSIFICAÇÃO DA ÁGUA DE REUSO}

Segundo Westerhoff (1984), o reuso de água é classificado em duas categorias: reuso potável e reuso não potável e essa classificação foi adotada pela Associação Brasileira de Engenharia Sanitária e Ambiental de São Paulo e divulgada nos Cadernos de Engenharia Sanitária e Ambiental. Essa classificação encontra-se detalhada na Figura 5.

Figura 5 - Classificação dos tipos de reuso

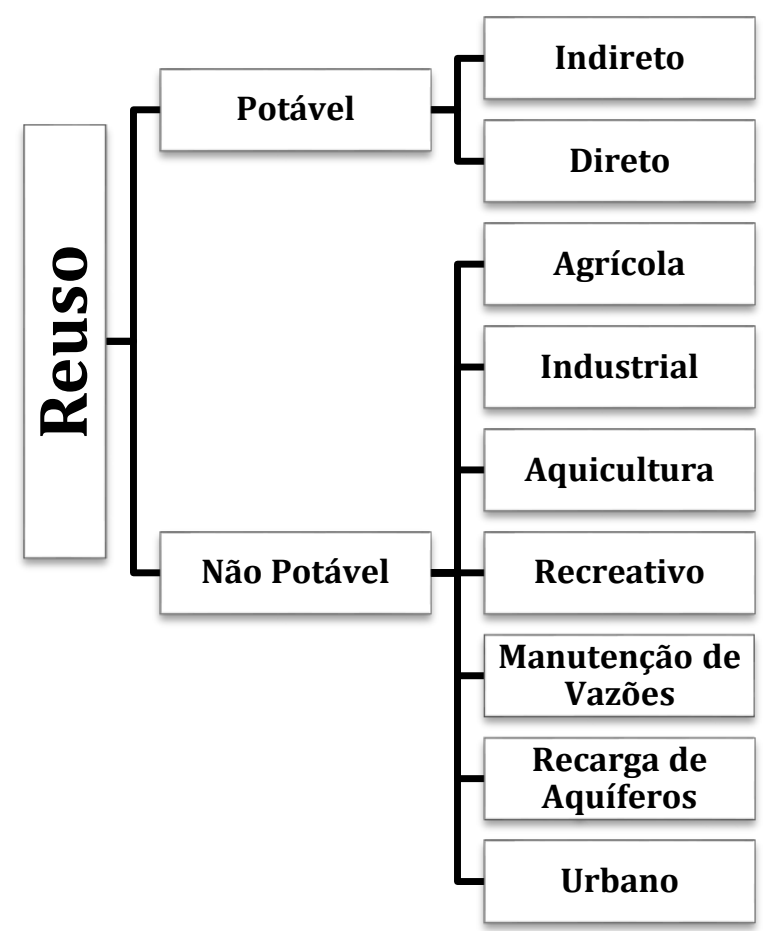

Fonte: Westerhoff (1984)

\subsubsection{REUSO POTÁVEL}

- Direto: quando as águas residuais recuperadas, por meio de tratamento avançado, são diretamente reutilizadas no sistema de água potável.

- Indireto: as águas residuais após tratamento, são dispostas na coleção de águas superficiais ou subterrâneas para diluição, purificação natural e subsequentemente captação, tratamento e finalmente utilizadas com água potável. 


\subsubsection{REUSO NÃO POTÁVEL}

- Para fins agrícolas: fertirrigação de plantas alimentícias, tais como árvores frutíferas, cereais, etc., e plantas não-alimentícias, tais como pastagens e forrageiras, e ainda dessedentação de animais.

- Para fins industriais: abrange os usos de refrigeração, águas de processo, para utilização em caldeiras, etc.

- Para fins urbanos: casos de reuso de água para rega de jardins, plantas ornamentais, campos de esportes e parques, para descargas sanitárias, lavagem de pavimentos e veículos, e enchimento de lagoas ornamentais, recreacionais, etc.

- Para manutenção de vazões de cursos d'água: utilização de efluentes tratados, visando uma adequada diluição de eventuais cargas poluidoras em cursos de água, incluindo-se fontes difusas, além de propiciar uma vazão mínima na estiagem.

- Para aquicultura: consiste na produção de peixes e plantas aquáticas visando à obtenção de alimentos e/ou energia, utilizando os nutrientes presentes nos efluentes tratados.

- Recarga de aquíferos subterrâneos: pode se dar de forma direta, pela injeção de efluente tratado sob pressão, ou de forma indireta, utilizando-se águas superficiais que tenham recebido descargas de efluentes tratados a montante.

As diretrizes são estabelecidas para minimizar as possibilidades de contaminação e orientar na tomada de decisões, proporcionando uma referência comum, para a criação de normas e padrões. Normalmente apresentam os tratamentos mínimos necessários, os padrões de qualidade exigidos para os usos, a eficiência exigida para o tratamento, a concepção do sistema de distribuição e o controle de usos de áreas. Os padrões são imposições legais estabelecidos por autoridade competente, através de leis ou regulamentos, a nível nacional, adaptando diretrizes às prioridades e levando em consideração as limitações, características técnicas, econômicas, sociais e culturais locais, os riscos e os benefícios (HESPANHOL, 1999).

O manual de reuso de água da Evironmental Protection Agency - EPA (2004), apresenta algumas diretrizes como: sugestões de processos de tratamento de efluentes; de qualidade da água para reuso; de monitoramento; e as distancias mínimas para proteger as fontes de água potável de contaminações e as pessoas de riscos à saúde, devido à exposição à água recuperada. As diretrizes sugeridas são apresentadas no Tabela 5 baseadas na 
informação de reuso nos Estados Unidos, porém condições locais podem limitar a aplicação destas diretrizes. 
Tabela 5 - Diretrizes sugeridas para o reuso da água

\begin{tabular}{|c|c|c|c|c|c|c|c|c|c|}
\hline \multirow[b]{2}{*}{ Tipos de Reuso } & \multirow[b]{2}{*}{ Tratamento } & \multicolumn{6}{|c|}{ Qualidade de água recuperada } & \multirow[b]{2}{*}{ Monitoramento de água recuperada } & \multirow[b]{2}{*}{ Distâncias recomendadas } \\
\hline & & $\mathrm{Ph}$ & DBO & Turbidez & SS & $\begin{array}{c}\text { Coliformes } \\
\text { Termotolerantes/ } \\
\text { 100mL }\end{array}$ & $\begin{array}{c}\text { Cloro } \\
\text { Residual }\end{array}$ & & \\
\hline Reuso Urbano & $\begin{array}{l}\text { Secundário } \\
\text { Filtração } \\
\text { Desinfecção }\end{array}$ & $6-9$ & $\begin{array}{l}\leq 10 \\
\mathrm{mg} / \mathrm{L}\end{array}$ & $\leq 2 \mathrm{uT}$ & - & Não detectável & $1 \mathrm{mg} / \mathrm{L}$ & $\begin{array}{c}\text { pH, DBO, Turbidez, Coliformes e Cloro } \\
\text { Residual }\end{array}$ & 15 m dos poços de captação de água potável. \\
\hline $\begin{array}{l}\text { Irrigação de } \\
\text { área de acesso } \\
\text { restringida }\end{array}$ & $\begin{array}{l}\text { Secundário } \\
\text { Desinfecção }\end{array}$ & $6-9$ & $\begin{array}{l}\leq 30 \\
\mathrm{mg} / \mathrm{L}\end{array}$ & - & $\begin{array}{r}\leq 30 \\
\mathrm{mg} / \mathrm{L}\end{array}$ & $\begin{array}{c}\leq 200 \text { coli } \\
\text { Termotolerantes/ } \\
\text { 100mL }\end{array}$ & $1 \mathrm{mg} / \mathrm{L}$ & $\begin{array}{c}\text { pH, DBO, Sólidos em Suspensão, Coliformes e } \\
\text { Cloro Residual }\end{array}$ & $\begin{array}{c}90 \text { m dos poços de captação de água } 30 \text { m de áreas } \\
\text { acessíveis ao público (se por aspersão). }\end{array}$ \\
\hline $\begin{array}{c}\text { Reuso na } \\
\text { agricultura }\end{array}$ & $\begin{array}{l}\text { Secundário } \\
\text { Filtração } \\
\text { Desinfecção }\end{array}$ & $6-9$ & $\begin{array}{l}\leq 10 \\
\mathrm{mg} / \mathrm{L}\end{array}$ & $\leq 2 \mathrm{uT}$ & - & Não detectável & $1 \mathrm{mg} / \mathrm{L}$ & $\begin{array}{c}\text { pH, DBO, Turbidez, Coliformes e Cloro } \\
\text { Residual }\end{array}$ & 15 m dos poços de captação de água potável. \\
\hline Recreação & $\begin{array}{l}\text { Secundário } \\
\text { Filtração } \\
\text { Desinfecção }\end{array}$ & $6-9$ & $\begin{array}{l}\leq 10 \\
\mathrm{mg} / \mathrm{L}\end{array}$ & $\leq 2 \mathrm{uT}$ & - & Não detectável & $1 \mathrm{mg} / \mathrm{L}$ & $\begin{array}{c}\text { pH, DBO, Turbidez, Coliformes e Cloro } \\
\text { Residual }\end{array}$ & $\begin{array}{l}150 \text { m dos poços de captação de água portável } \\
\text { (mínimo) se o fundo não for impermeabilizado. }\end{array}$ \\
\hline Paisagístico & $\begin{array}{l}\text { Secundário } \\
\text { Desinfecção }\end{array}$ & - & $\begin{array}{l}\leq 30 \\
\mathrm{mg} / \mathrm{L}\end{array}$ & - & $\begin{array}{r}\leq 30 \\
\mathrm{mg} / \mathrm{L}\end{array}$ & $\begin{array}{c}\leq 200 \text { coli } \\
\text { Termotolerantes/ } \\
100 \mathrm{~mL}\end{array}$ & $1 \mathrm{mg} / \mathrm{L}$ & $\begin{array}{c}\text { DBO, Sólidos em Suspensão, Coliformes e } \\
\text { Cloro Residual }\end{array}$ & $\begin{array}{l}150 \text { m dos poços de captação de água portável } \\
\text { (mínimo) se o fundo não for impermeabilizado. }\end{array}$ \\
\hline $\begin{array}{c}\text { Usos na } \\
\text { Construção }\end{array}$ & $\begin{array}{l}\text { Secundário } \\
\text { Desinfecção }\end{array}$ & - & $\begin{array}{r}\leq 30 \\
\mathrm{mg} / \mathrm{L}\end{array}$ & - & $\begin{array}{r}\leq 30 \\
\mathrm{mg} / \mathrm{L}\end{array}$ & $\begin{array}{c}\leq 200 \text { coli } \\
\text { Termotolerantes/ } \\
100 \mathrm{~mL}\end{array}$ & $1 \mathrm{mg} / \mathrm{L}$ & $\begin{array}{c}\text { DBO, Sólidos em Suspensão, Coliformes e } \\
\text { Cloro Residual }\end{array}$ & - \\
\hline $\begin{array}{l}\text { Reuso potável } \\
\text { indireto }\end{array}$ & $\begin{array}{c}\text { Secundário } \\
\text { Filtração } \\
\text { Desinfecção } \\
\text { Tratamento } \\
\text { Avançado }\end{array}$ & $\begin{array}{c}6,5- \\
8,5\end{array}$ & & $\leq 2 \mathrm{uT}$ & - & Não detectável & $1 \mathrm{mg} / \mathrm{L}$ & $\begin{array}{c}\text { pH, Turbidez, Coliformes, Cloro Residual, } \\
\text { padrões de qualidade de água - } \\
\text { trimestralmente }\end{array}$ & $\begin{array}{l}600 \text { m de poços de extração, podendo variar de } \\
\text { acordo com as condições específicas do local. }\end{array}$ \\
\hline
\end{tabular}




\subsection{LEIS, NORMAS E PADRÕES DO REUSO DA ÁGUA NO BRASIL}

No Brasil, não existem normas e padrões específicos para regulamentar e direcionar o reuso de águas residuárias e isto se deve à falta de tradição quanto à aplicação desta prática. A legislação apenas estabelece limites máximos de impureza para cada destino específico da água. Estes limites, chamados de padrões de qualidade, foram estabelecidos em 1986 pela resolução no 20 do Conselho Nacional do Meio Ambiente (CONAMA), atualizada para resolução no 357/2005. A Resolução define quatro classes e mais uma especial, e classifica as águas como doces, salobras e salinas, estabelecendo parâmetros físico-químicos para cada classe dos corpos d'água, de acordo com a utilização que deve ser dada às mesmas. Apesar de a Resolução definir padrões para o lançamento de efluentes, vale ressaltar que as regras estabelecidas não satisfazem os problemas que eventualmente podem aparecer no reuso de águas residuais (MIERZWA, 2002; PASCHOLATO ET AL., 2004; VIVACQUA, 2005).

Para que o reuso seja praticado de forma segura é imprescindível que especificações legais para a qualidade da água sejam determinadas por órgãos públicos, sejam eles de caráter internacional, nacional, regional ou local, conforme recomenda Escalera (1995). O autor ainda lembra que os padrões especificados podem variar de acordo com as diferenças de cada localidade, mesmo dentro de um mesmo país. Por exemplo, de acordo com Santos (1993), em todo o mundo, o reuso de água tem sido praticado com base nas determinações da OMS e da EPA. Porém, mesmo entre aquelas organizações, há diferenças quanto às orientações a serem seguidas. No caso de países onde as infecções parasitárias são comuns, as orientações recomendadas pela OMS para o reuso de água são menos restritivas, quando comparadas com os da EPA, sendo dirigidas, principalmente, para a remoção de helmintos.

Assim como já destacado no Brasil, ainda não há normalização específica para os sistemas de reuso da água. O que se tem praticado é a adoção dos padrões internacionais ou mesmo a adoção de orientações técnicas produzidas por instituições privadas (GIACCHINI, 2010).

As avaliações legais têm se baseado nas legislações de outros países, principalmente nos critérios de qualidade para reuso da Organização Mundial da Saúde (OMS), entendida como referência mundial.

Um exemplo disso são as especificações publicadas no manual elaborado pela Funasa, que trata, entre outros aspectos, da grande importância aos aspectos estéticos da água 
reciclada. De acordo com o manual, para um reuso vinculado ao adorno arquitetônico, exigese grau de transparência, ausência de cor, odor, escuma, ou qualquer outra substância ou componentes flutuantes (FUNASA, 2004).

Mesmo com o aparato legal referente aos recursos hídricos e tendo possibilidade de implantar novas leis relativas ao reuso, é pouco provável que no Brasil se estabeleça um único programa de reuso em nível nacional. Iniciativas regionais talvez sejam mais adequadas devido às proporções geográficas e às características distintas de cada região. Os projetos serão bem-sucedidos quando houver um esforço conjunto das secretarias municipais e estaduais com as companhias de saneamento (HESPANHOL, 2003 apud ALMEIDA 2011). 


\section{METODOLOGIA}

A pesquisa proposta foi de cunho experimental, sendo utilizada uma Estação Piloto de Tratamento de Água (ETA-piloto) em uma residência definida para este estudo. A casa está situada, geograficamente, na Região Administrativa da Candangolândia, Distrito Federal, e é constituída de três pavimentos em alvenaria, possuindo dois banheiros no segundo pavimento e dois lavabos, um no térreo e o outro no terceiro pavimento. Possui também uma sala, cozinha, copa, despensa e uma garagem, todos no pavimento térreo. No segundo pavimento existem três quartos, sendo uma suíte. O terceiro pavimento, local onde foi instalada a ETApiloto, é composto por uma área gourmet e uma área de serviço. A residência possui uma família de 4 (quatro) pessoas. A Figura 6 mostra a vista geral da residência escolhia para o trabalho.

Figura 6 - Vista de frente da residência utilizada no estudo de água de reuso

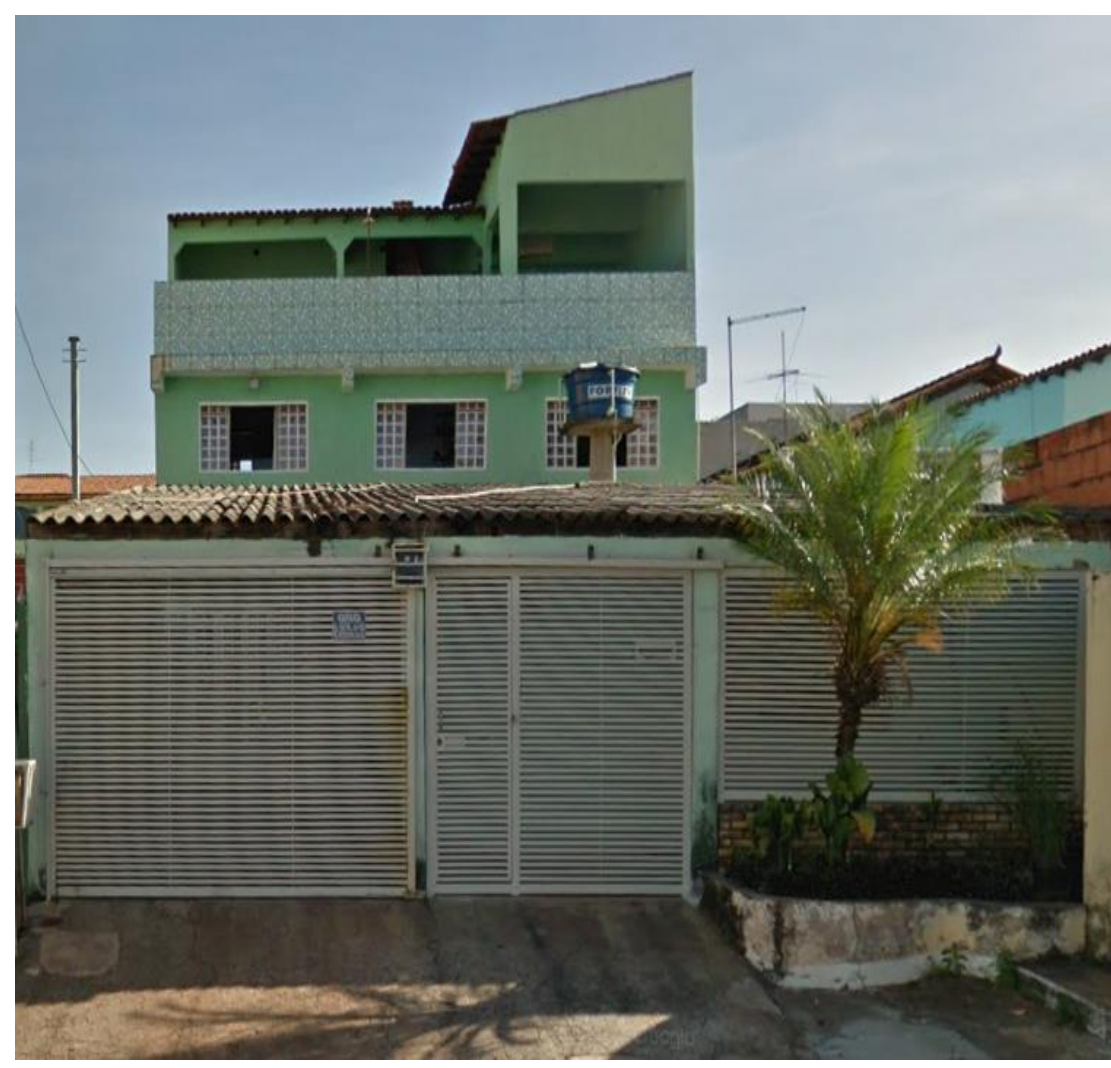

Fonte: Autor

O projeto proposto teve como objetivo executar a melhoraria dos efluentes de interesse, direcionando-os para o sistema de tratamento e, em seguida, após armazená-los, esse efluente foi encaminhado para os pontos da casa onde ocorreu a utilização efetiva. 
Embora a utilização das águas cinza, como alternativa em tempos de escassez de água, tenha sido proposta como objeto de estudo, cabe ressaltar que estas águas, devido as suas origens, são de difícil caracterização em virtude da diversidade de produtos químicos utilizados e ao fato delas poderem estar ou não contaminadas por patógenos. Desta forma, o primeiro passo para a realização deste trabalho foi a caracterização das águas cinza, de modo a viabilizar sua utilização de forma segura.

\subsection{SISTEMA DE REUSO}

O sistema experimental de reuso utilizado para a coleta de amostras de águas cinza foi construído ao lado da área de serviço, pois a água bruta era oriunda da máquina de lavar e do tanque. O sistema de captação desta água permite que ela escoe para o reservatório de água bruta ou para o sistema de esgoto, caso seja necessário através de um registro de gaveta de DN 50. O material utilizado para a formação do sistema foi composto de caixas d'água para diferentes finalidades (reservatórios e filtro).

A ETA-piloto (Figura 7) foi constituída por:

- Reservatório de água bruta 1: capacidade de armazenamento de 500 L. Recebia a água proveniente da máquina de lavar roupas e do tanque.

- Reservatório de água bruta 2: capacidade de armazenamento de 250 L ficava a uma altura de 2,08m do piso. Recebia a água recalcada proveniente do reservatório 1 . Para o recalque da água foi utilizada uma bomba d'água elétrica periférica de 1 HP.

- Filtro: capacidade de armazenamento de $100 \mathrm{~L}$, composto por uma camada de seixo com granulometria $19 \mathrm{~mm}$ a uma espessura de $7 \mathrm{~cm}$ e outra camada de seixo com granulometria $9,5 \mathrm{~mm}$ e espessura $9 \mathrm{~cm}$, uma camada de areia para filtro com granulometria $2,4 \mathrm{~mm}$ e espessura $5 \mathrm{~cm}$ e uma camada de carvão ativado com granulometria $2,4 \mathrm{~mm}$ e espessura 4 cm. Todas as camadas foram separadas por manta geotêxtil, para que não houvesse mistura de material e para ajudar na filtragem.

- Reservatório de água tratada: capacidade de armazenamento de 500 L, recebia a água após tratamento. Esse reservatório foi dotado, em sua parte inferior, de um ponto de distribuição. 
Figura 7 - Vista geral da ETA-piloto

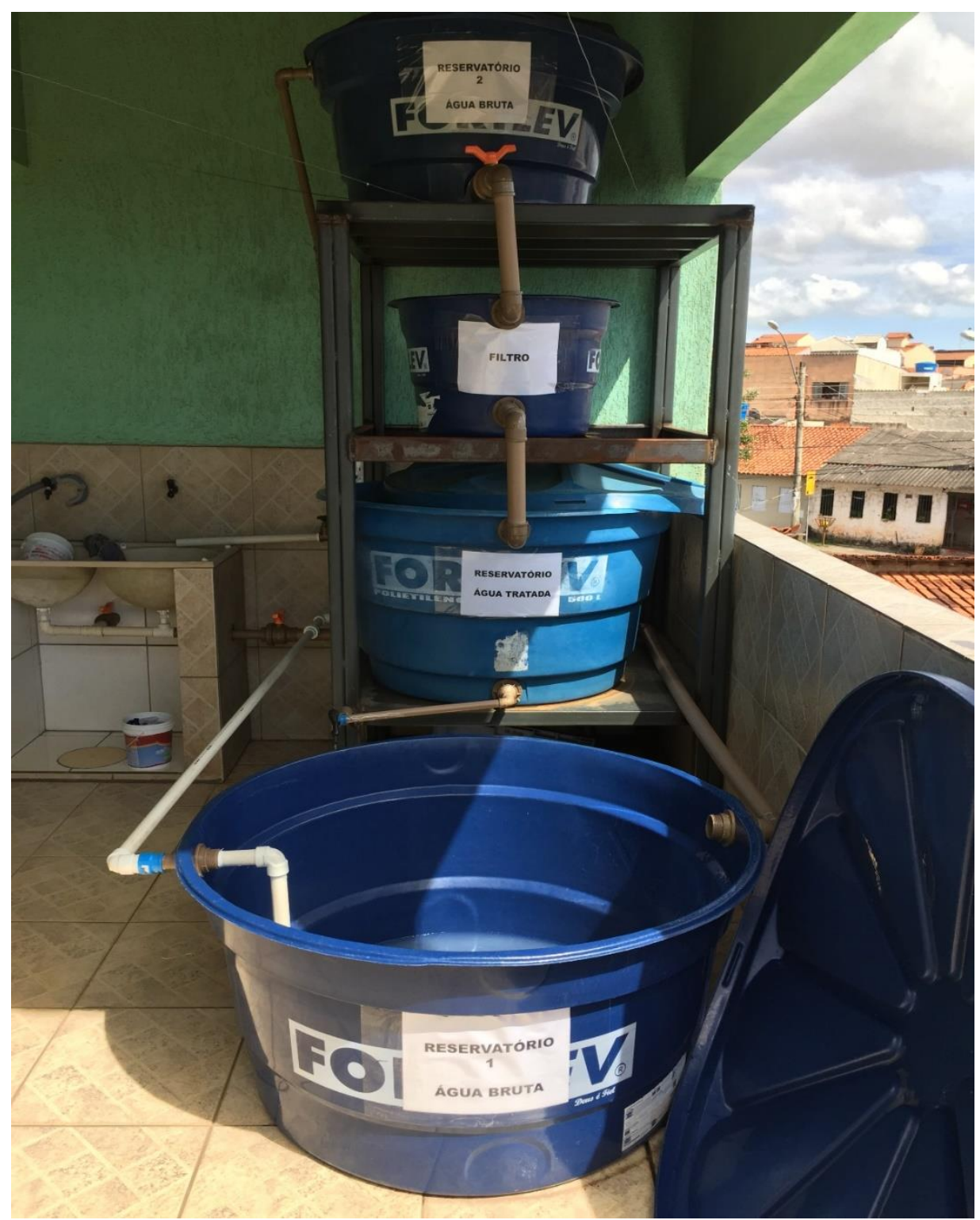

Fonte: autor

O sistema de filtração da ETA-piloto operava em fluxo descendente, onde a água escoava através do meio filtrante já descrito. Dessa forma, a filtração ocorreu por ação da gravidade, conforme pode ser observado nas Figuras 7 e 9.

Durante o trabalho, foi efetuada a caracterização da água de reuso que seria utilizada na pesquisa. Tratou-se, portanto, de uma água cinza clara, pois a mesma não era proveniente de pia de cozinha ou de máquina de lavar pratos. Desse modo, quando a água possui essas origens, ela é caracterizada como água cinza escura, conforme classificação de água de reuso estabelecida por Henze \& Ledin, 2001 apud MAY, 2009. 
Os efluentes dos dois pontos de amostragem foram coletados em 6 frascos, utilizando 3 frascos para coleta em cada ponto como recomendado pelo laboratório, sendo um dos frascos de âmbar de $250 \mathrm{~mL}$, e os outros dois de plástico, um com $500 \mathrm{~mL}$ e outro com capacidade de $1 \mathrm{~L}$, todos fornecidos pelo Laboratório Tommasi, o qual realizou as análises dos seguintes parâmetros:

- Demanda Bioquímica de Oxigênio - DBO;

- Cor Verdadeira;

- Turbidez;

- $\mathrm{pH}$;

- Cloro Residual Livre;

- Coliformes Totais;

- Coliformes Termotolerantes.

Após a coleta, as amostras foram levadas, imediatamente, ao laboratório para a realização das análises à luz das diretrizes estabelecidas no Standard methods for the examination of water and waster and wastwater-SMWW (2005).

As coletas de amostras de água para análise foram realizadas durante cada carreira de filtração. Foram realizadas três carreiras de filtração com as características mostradas no Tabela 6.

Tabela 6 - Caraterísticas das carreiras de filtração utilizadas na ETA - Piloto

\begin{tabular}{|c|c|}
\hline Carreira de filtração & Características do leito filtrante \\
\hline 1 & Seixo \\
\hline 2 & Seixo + manta sintética + areia \\
\hline 3 & Seixo + manta sintética + areia + manta sintética + carvão ativado \\
\hline
\end{tabular}

Fonte: Autor

Por meio de ensaios realizados no laboratório de solos do Centro Universitário de Brasília (Uniceub), foram determinadas as granulometrias dos agregados filtrantes, sendo eles: areia, seixos e carvão ativado. Como não existem normas para definir granulometria do carvão e dos seixos, os mesmos foram definidos de acordo com as características da areia e da brita respectivamente. A NM 248:2001 Agregados - Determinação da composição granulométrica, foi a norma utilizada para determinar as granulometrias.

O procedimento para a avaliação do processo de tratamento da água cinza oriundas da máquina de lavar roupa e do tanque foi a realização de ensaios de tratabilidade da água, 
por análises físico, químico e microbiológico. A Figura 8 mostra o filtro completo com os seixos, areia e o carvão utilizados no trabalho.

Figura 8 - Filtro composto por seixos, areia e carvão ativado

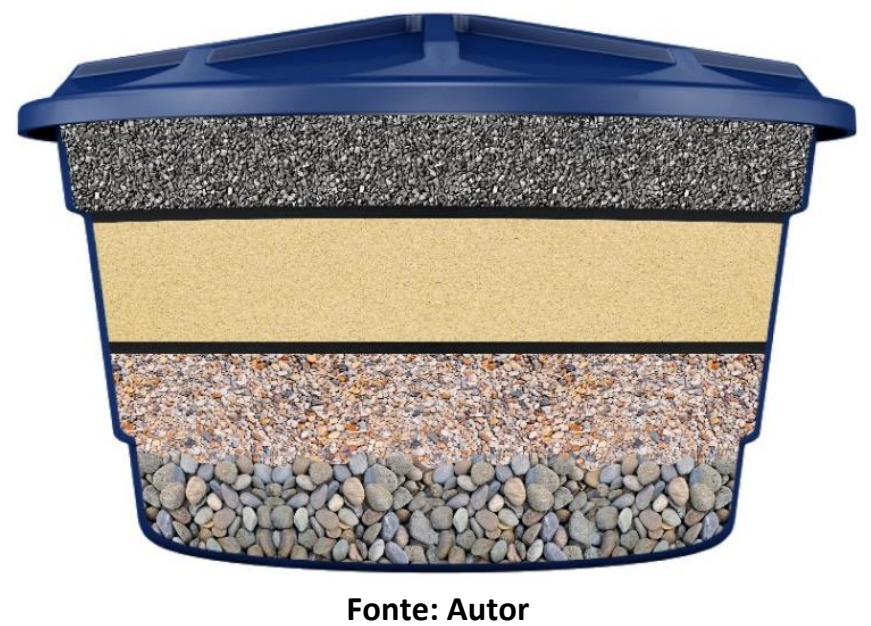

Para que o funcionamento do sistema ocorresse de forma adequada, fez-se necessário o uso de tubulações e conexões descritas na Tabela 7. 
Tabela 7 - Tubulações e Conexões utilizadas na ETA-piloto

\begin{tabular}{|c|c|c|c|c|c|c|c|c|c|c|c|c|c|}
\hline Trecho & $\begin{array}{c}\text { Registro } \\
\text { de Gaveta } \\
\text { (UN) }\end{array}$ & $\begin{array}{l}\text { Joelho90 } \\
\text { (UN) }\end{array}$ & $\begin{array}{c}\text { Joelho } 450 \\
\text { Soldável } \\
\text { (UN) }\end{array}$ & $\begin{array}{c}\text { Tubulação } \\
\text { DN } 25 \\
\text { (m) }\end{array}$ & $\begin{array}{c}\text { Tubulação } \\
\text { DN } 40 \\
\text { (m) }\end{array}$ & $\begin{array}{c}\text { Tubulação } \\
\text { DN } 50 \\
\text { (m) }\end{array}$ & $\begin{array}{c}\text { Adaptador } \\
\text { Soldável } \\
\text { com Anel } \\
\text { para Caixa } \\
\text { d'Água (UN) }\end{array}$ & $\begin{array}{l}\text { Válvula } \\
\text { retentora } \\
\text { (UN) }\end{array}$ & $\begin{array}{c}\text { Luva } \\
\text { Soldável } \\
\text { com Bucha } \\
\text { de Latão } \\
\text { (UN) }\end{array}$ & $\begin{array}{c}\text { Torneira } \\
\text { esfera de } \\
\text { metal (UN) }\end{array}$ & $\begin{array}{c}\text { Bomba } \\
\text { d'água } \\
\text { elétrica } \\
\text { periférica } \\
\text { de } \\
1 \mathrm{HP}(\mathrm{UN})\end{array}$ & $\begin{array}{c}\text { Tê } \\
\text { roscável } \\
\text { (UN) }\end{array}$ & $\begin{array}{c}\text { União } \\
\text { roscável } \\
\text { (UN) }\end{array}$ \\
\hline R1 para R2 & 1 & 3 & 1 & & 3,95 & 2 & 2 & 1 & 1 & & 1 & 1 & 2 \\
\hline $\begin{array}{l}\text { R2 para } \\
\text { Filtro }\end{array}$ & 1 & & & & & 0,49 & 2 & & & & & & \\
\hline $\begin{array}{c}\text { Filtro para } \\
\text { Reservatório } \\
\text { de água } \\
\text { tratada } \\
\end{array}$ & & 2 & & & & 0,64 & 2 & & & & & & \\
\hline Distribuição & & 2 & & 0,56 & & & 1 & & & 1 & & & \\
\hline
\end{tabular}

Fonte: Autor

Legenda:

R1- Reservatório inferior de água bruta

R2- Reservatório superior de água bruta 
Figura 9 - Fluxograma da ETA-piloto

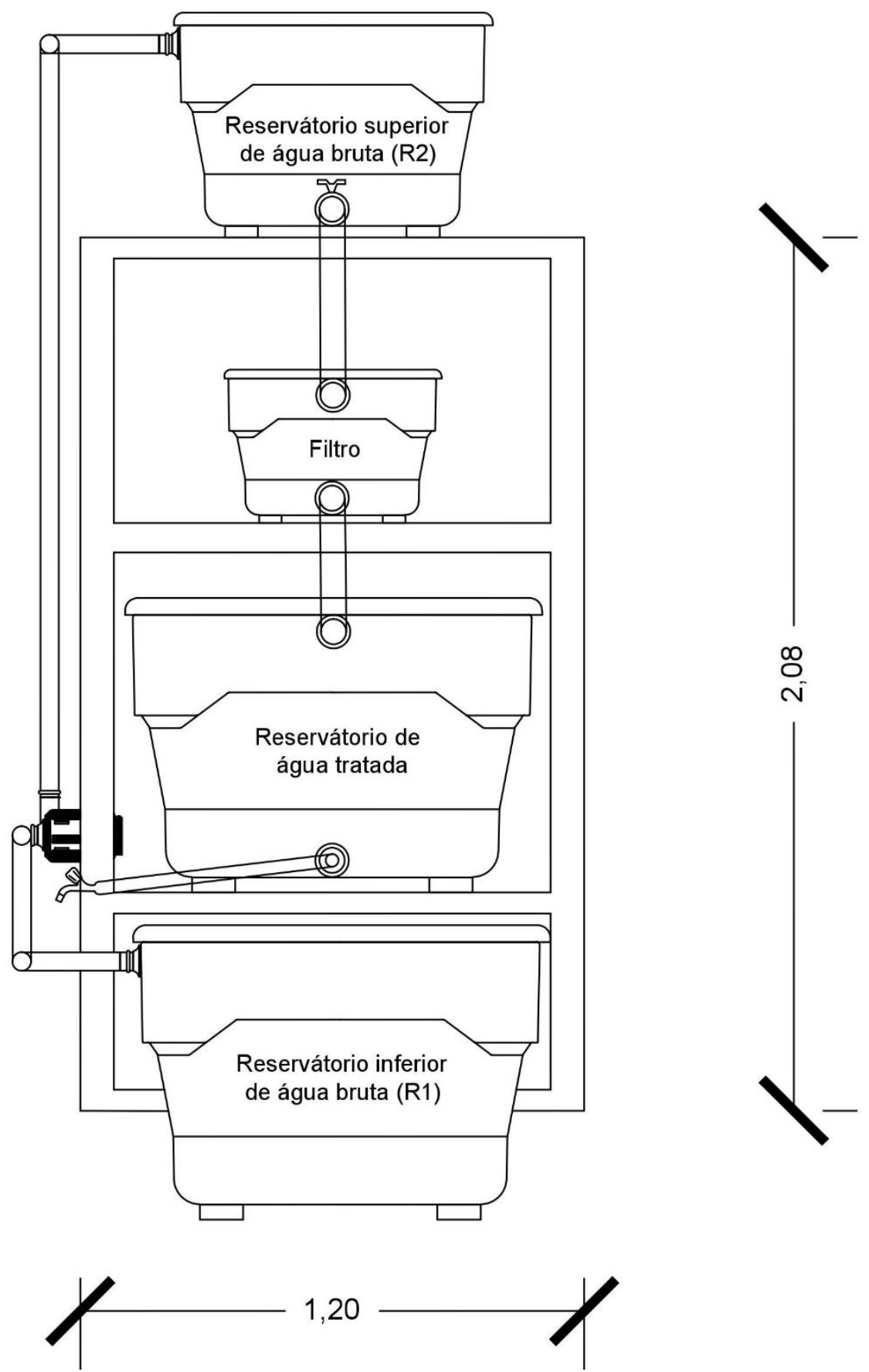

Fonte: Autor

Foram calculadas as vazões, perdas de carga e número de Reynolds em todos os trechos da ETA-piloto (Tabela 8). Para os cálculos de perda de carga, foi utilizada a formula universal, baseando no ábaco de Moody (Anexo II), e para determinar as perdas de carga localizadas, utilizou-se a tabela apresentada por Hélio Creder (2012) (Anexo III). O Anexo I apresenta o memorial de cálculo para obtenção dos resultados. 
Tabela 8 - Vazão, perda de carga e Reynolds

\begin{tabular}{|c|c|c|c|}
\hline Trecho & Vazão (L/s) & Perda de carga (m) & Reynolds \\
\hline R1 para R2 & $5,55 \times 10^{-1}$ & $1,33 \times 10^{-1}$ & Regime turbulento \\
\hline $\begin{array}{c}\text { R2 para Filtro (registro } \\
\text { pouco aberto) }\end{array}$ & $1,33 \times 10^{-2}$ & $1,40 \times 10^{-2}$ & Regime laminar \\
\hline $\begin{array}{c}\text { R2 para Filtro (registro } \\
\text { totalmente aberto) }\end{array}$ & $2,79 \times 10^{-1}$ & $4,23 \times 10^{-2}$ & Regime turbulento \\
\hline $\begin{array}{c}\text { Filtro (registro pouco } \\
\text { aberto) para } \\
\text { Reservatório de água } \\
\text { tratada }\end{array}$ & $1,20 \times 10^{-2}$ & $9,08 \times 10^{-6}$ & Regime laminar \\
\hline $\begin{array}{c}\text { Filtro (registro } \\
\text { totalmente aberto) para } \\
\text { Reservatório de água } \\
\text { tratada }\end{array}$ & $1,51 \times 10^{-1}$ & $9,17 \times 10^{-4}$ & Regime turbulento \\
\hline Distribuição & $8,19 \times 10^{-2}$ & $5,62 \times 10^{-3}$ & Regime turbulento \\
\hline
\end{tabular}

Fonte: Autor

Legenda:

R1 - Reservatório inferior de água bruta

R2- Reservatório superior de água bruta 


\section{RESULTADOS E DISCUSSÕES}

A operação da ETA-piloto aconteceu por etapas, sendo denominadas de carreiras de filtração. Assim, no total, foram realizadas três carreiras de filtração e, em cada uma delas, foram realizadas análises de sensibilidade do sistema de tratamento, a fim de corrigir possíveis falhas de funcionamento.

Na primeira etapa, foi possível constatar que o sistema de drenagem do filtro entupiu rapidamente. Isso ocorreu devido ao fato da manta colocada na tubulação de saída da água ser muito fina. Para corrigir esse problema, optou-se por substituir a manta por uma tela de aço inox, conforme pode ser observado na Figura 10.

Figura 10 - Sistema de saída água do filtro com uso de manta e com uso de tela de aço inox

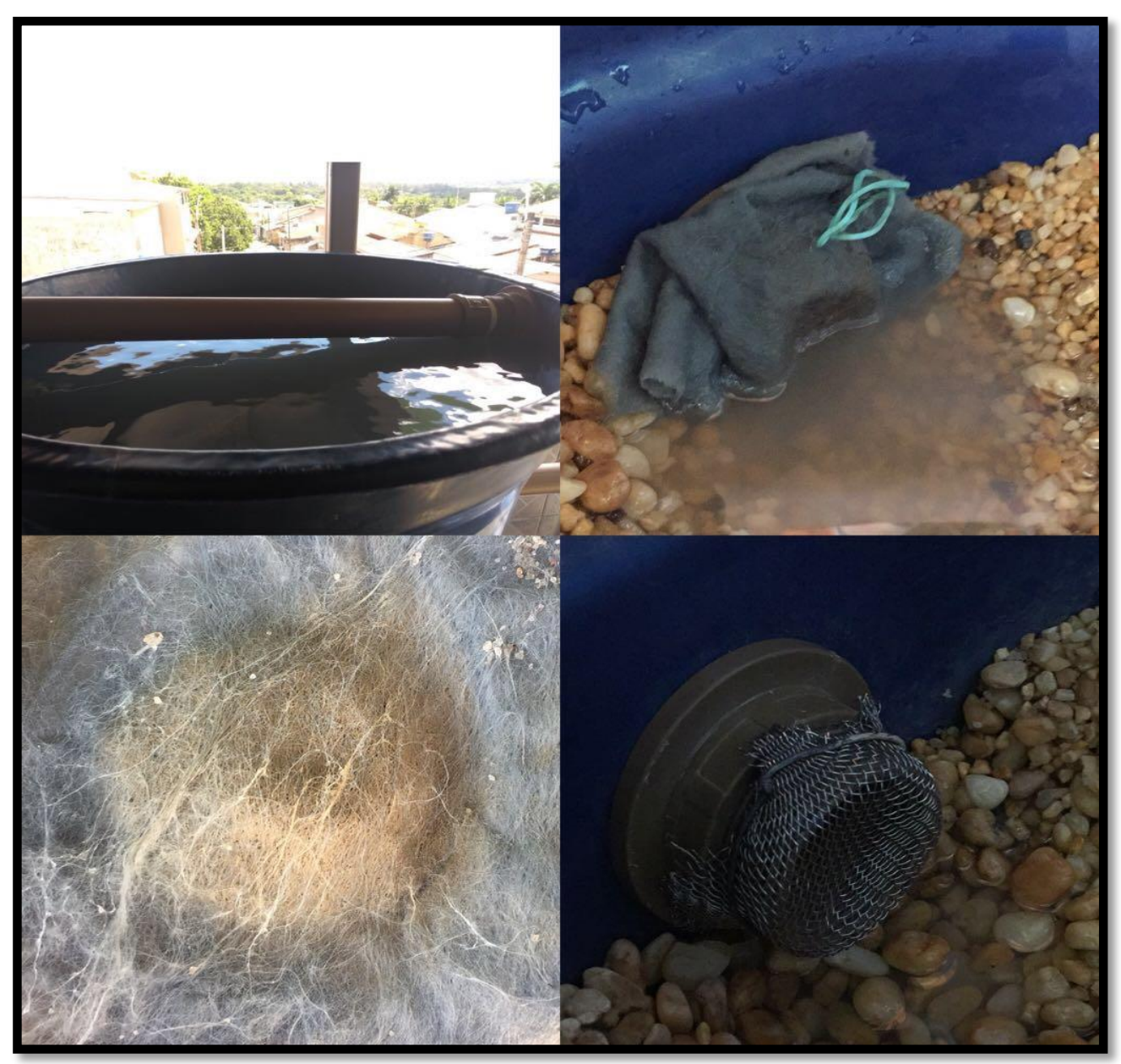

Fonte: Autor 
Como já mencionado no item 4.1, foi utilizada uma bomba d'água para levar a água do reservatório inferior de água bruta 1 para o reservatório superior de água bruta 2. Assim, observou-se que devido às sujeiras acumuladas no reservatório 1, poderia ocorrer dificuldade de funcionamento da válvula de retenção, a qual foi instalada no fim da tubulação submersa do reservatório 1. Essa válvula também foi responsável pelo travamento da bomba quando o nível da água atingia determinado nível. Inicialmente, todos estes problemas causaram entradas de ar na tubulação e, consequentemente, problemas operacionais no sistema.

Após todos os processos de operação da ETA-piloto, verificou-se que restava água entre o ponto de saída e o fundo do reservatório, gerando problemas não mensurados inicialmente no projeto, tais como: odor e decomposição da água restante. Realizava-se, então, dois processos para facilitar o escoamento dessa água: primeiro, uma limpeza manual, com a retirada de toda água e lavagem do reservatório e, segundo, agregava-se outro volume de água, proveniente da máquina de lavar ou do tanque, misturando-se, assim, com a água já existente. Esses procedimentos eliminavam ou diminuíam o odor da água.

Após a correção dos problemas iniciais, foi realizada, efetivamente, a primeira carreira de filtração. Nessa etapa, o filtro da ETA-piloto foi constituído de duas camadas de seixos. Nirenberg e Reis (2010) ressaltam que a camada de seixos possui a função de formar uma colônia de bactérias para degradação da matéria orgânica presente na água, devido ao seu alto índice de vazios, o que também permite altas taxas de permeabilidade e infiltração.

A primeira camada de seixos (Figura 11) possuía granulometria de $19 \mathrm{~mm}$ e foi posta com uma espessura de $7 \mathrm{~cm}$ e, em seguida, foi sobreposta a segunda camada, que apresentava granulometria de $9,5 \mathrm{~mm}$ com a espessura de $9 \mathrm{~cm}$. As espessuras das camadas foram definidas pelos pesquisadores, não permitindo que ultrapassasse o limite do filtro que dispunha de um diâmetro de $73 \mathrm{~cm}$ com altura total de $41 \mathrm{~cm}$. 
Figura 11 - Configuração do filtro durante a primeira carreira de filtração

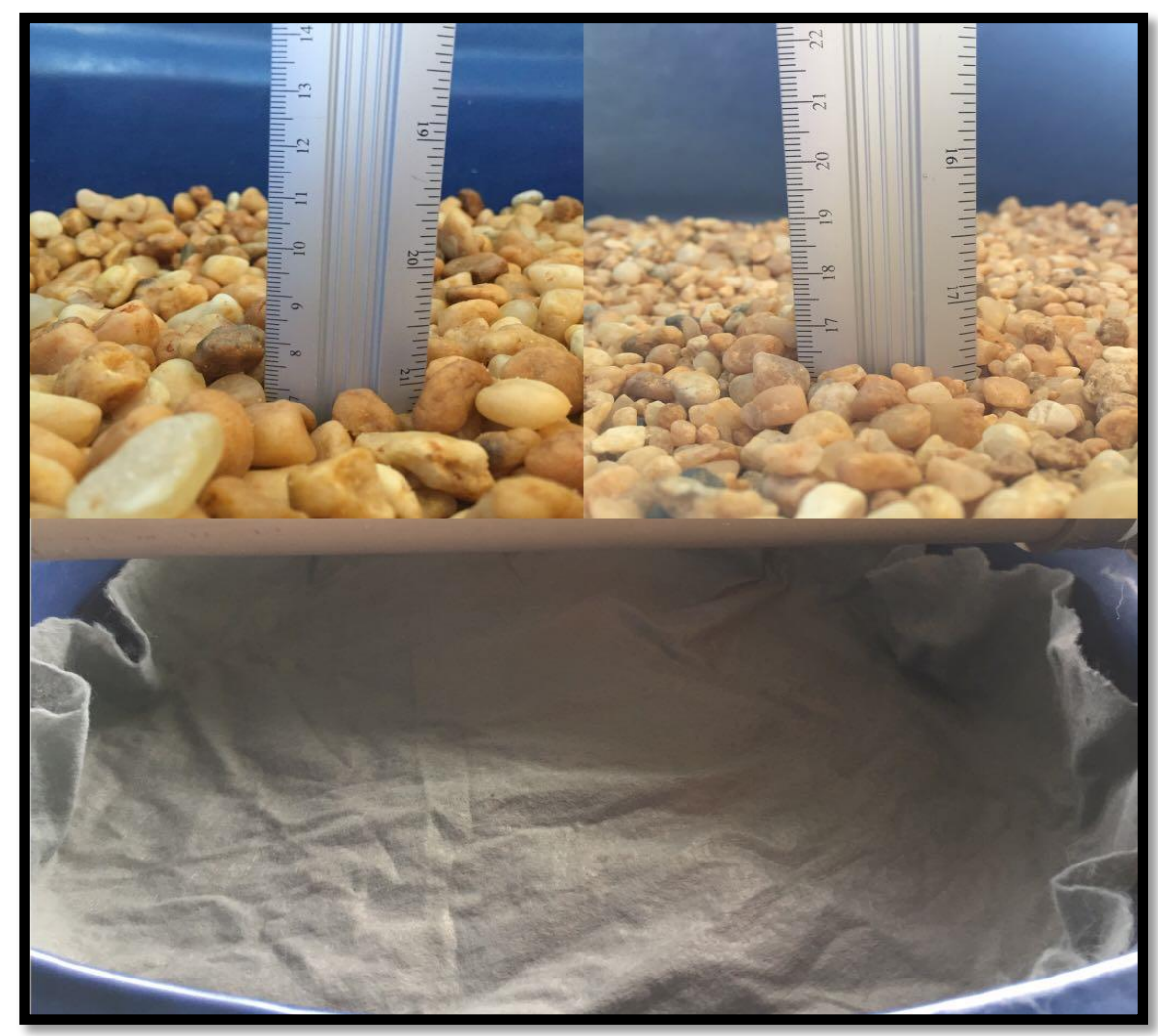

Fonte: Autor

Na primeira etapa, a ETA-piloto operou com uma vazão de $1,33 \times 10^{-2} \mathrm{~L} / \mathrm{S}$ e percebeuse que a estrutura montada poderia ser reduzida, a fim de se ajustar em residências menores; contudo, devido ao tempo limitado para a realização do trabalho, tal redução não foi realizada e as demais etapas da pesquisa foram realizadas com a mesma estrutura, sendo alterados, apenas, a configuração do meio filtrante. A discussão sobre um novo modelo de ETA-piloto para água de reuso será abordado mais adiante.

As coletas da água para análise laboratorial foram realizadas em dois pontos: coleta de água bruta (água que não passou pelo filtro) e coleta de água tratada. Dessa forma, pôde-se avaliar as condições da qualidade da água antes e pós tratamento pelo processo de filtração. O resultado da análise da água bruta e da agua tratada encontram-se na Tabela 9. 
Tabela 9 - Primeira carreira de filtração: filtro com seixos

\begin{tabular}{|l|l|c|}
\hline \multicolumn{1}{|c|}{ Parâmetros } & Água Bruta & Água tratada \\
\hline DBO & $590,0 \mathrm{mg} / \mathrm{L}$ & $3,96 \mathrm{mg} / \mathrm{L}$ \\
\hline Cor & $2.340 \mathrm{mgPt}-\mathrm{Co} / \mathrm{L}$ & $2.371 \mathrm{mgPt}-\mathrm{Co} / \mathrm{L}$ \\
\hline Turbidez & $519 \mathrm{UNT}$ & $580,00 \mathrm{UNT}$ \\
\hline Ph & 7,53 & 6,69 \\
\hline Cloro Residual Livre & $0,06 \mathrm{mg} / \mathrm{L}$ & $0,52 \mathrm{mg} / \mathrm{L}$ \\
\hline Coliformes Totais & ND & ND \\
\hline Coliformes Termotolerantes & ND & ND \\
\hline
\end{tabular}

Legenda:

ND: Não Detectado

UNT: Unidade Nefelométrica de Turbidez

Fonte: Autor

Observando-se os resultados mostrados na Tabela 9, percebe-se que há um aumento no resultado da cor verdadeira e da turbidez na água tratada. Esse aumento foi decorrente dos resíduos que estavam nos seixos e que se desprenderam com a passagem da água, levando, assim, ao aumento desses parâmetros após o tratamento. Em relação aos parâmetros microbiológicos, é possível inferir que os produtos químicos utilizados na máquina de lavar (água bruta) parecem ter sido suficientes para reduzir a quantidade desses organismos ao nível de não serem detectados nas análises laboratoriais realizadas. Logo, no geral, pode-se considerar que a primeira carreira de filtração foi utilizada para calibrar a ETA piloto, determinando-se os parâmetros hidráulicos de funcionamento.

Visto que na primeira carreira de filtração não foram obtidos resultados satisfatórios, pois os parâmetros cor verdadeira, turbidez e cloro residual livre não atingiram os valores esperados para o reuso urbano, houve a necessidade de inserir mais uma camada de meio filtrante, no caso, foi utilizada a areia, conforme pode ser observado na Figura 12. Essa areia possuia granulometria de $2,4 \mathrm{~mm}$, sendo classificada como areia média. Com essa nova configuração do filtro (duas camadas de seixos e areia), esperou-se conseguir uma maior redução da turbidez e, consequentemente, da cor verdadeira. 
Figura 12 - Camada de areia

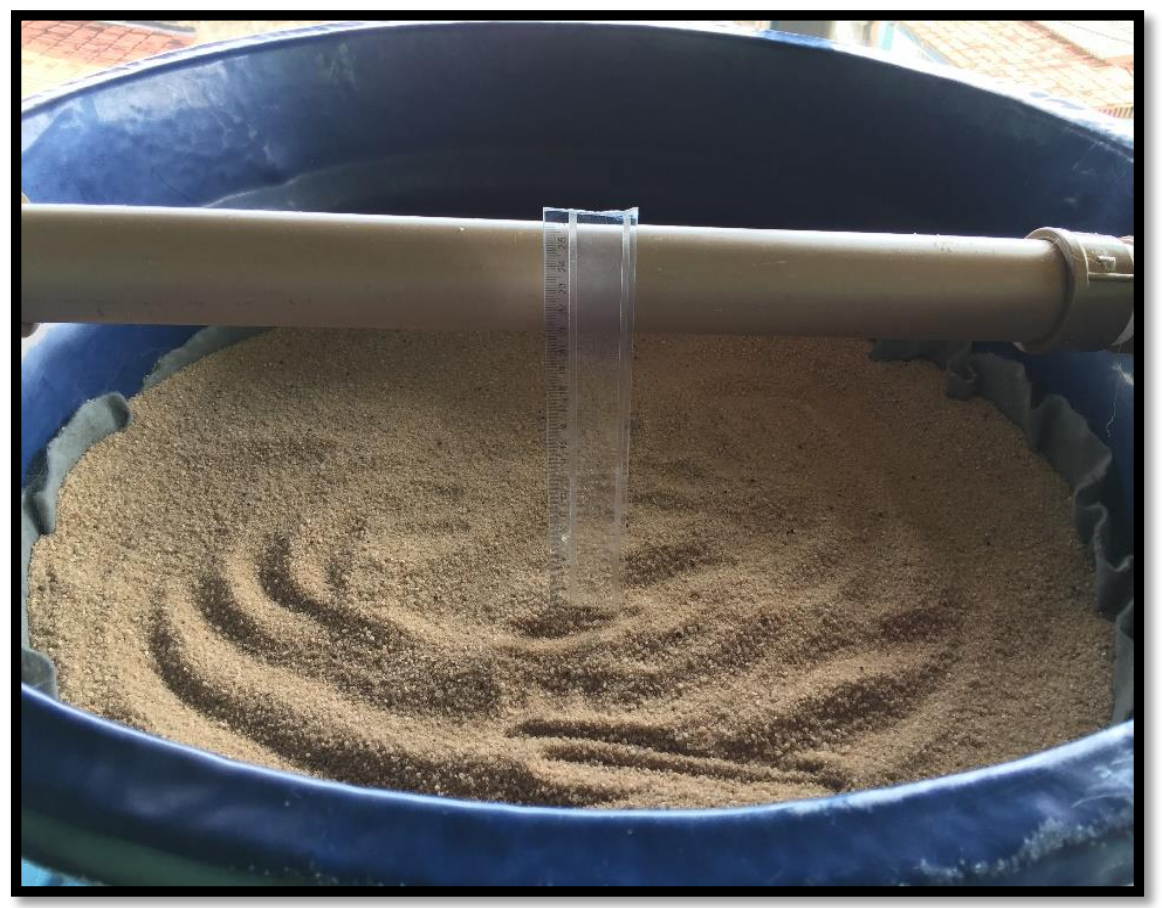

Fonte: Autor

Foi adicionado também uma manta geotêxtil antes de acomodar a camada de areia para auxiliar na retenção das partículas. A camada de areia tinha uma espessura de $5 \mathrm{~cm}$. Assim, repetiu-se o mesmo procedimento operacional adotado na primeira carreira de filtração, ou seja, com coleta da água bruta e de água tratada. O resultado da análise dessas amostras é mostrado na Tabela 10.

Tabela 10 - Segunda carreira de filtração: filtro com seixos, manta sintética e areia

\begin{tabular}{|l|l|l|}
\hline \multicolumn{1}{|c|}{ Parâmetros } & Água Bruta & Água tratada \\
\hline Cor & $2.340 \mathrm{mgPt}-\mathrm{Co} / \mathrm{L}$ & $2.084 \mathrm{mgPt}-\mathrm{Co} / \mathrm{L}$ \\
\hline Turbidez & $519 \mathrm{UNT}$ & $430 \mathrm{UNT}$ \\
\hline $\mathrm{pH}$ & 7,53 & 6,94 \\
\hline Cloro Residual Livre & $0,06 \mathrm{mg} / \mathrm{L}$ & $0,21 \mathrm{mg} / \mathrm{L}$ \\
\hline Coliformes Totais & ND & $\mathrm{ND}$ \\
\hline Coliformes Termotolerantes & ND & ND \\
\hline
\end{tabular}

Legenda:

ND: Não Detectado

UNT: Unidade Nefelométrica de Turbidez

Fonte: Autor 
Observando-se a Tabela 10, nota-se, no que se refere à água tratada, que houve uma redução da cor e da turbidez da ordem de $11 \%$ e de $17 \%$, respectivamente. Com o leito filtrante composto de seixos, manta e areia, esperava-se que a redução desses parâmetros fosse maior, particularmente no que tange à turbidez; entretanto, o resultado encontrado pode ter sido reflexo de ajustes hidráulicos incompletos na ETA - piloto, como por exemplo, a taxa de velocidade aplicada.

A taxa da velocidade da água que entra no filtro foi controlada manualmente por meio de registro de gaveta, que foi instalado na saída do reservatório 2 de água bruta, este, foi aberto de modo que a filtração fosse lenta, proporcionando vazão correspondente a $0,0133 \mathrm{l} / \mathrm{s}$ e uma perda de carga de $1,4 \times 10^{-2} \mathrm{~m}$. O registro foi completamente aberto apenas para realizar a limpeza da ETA-piloto, e ainda sim deve de ser controlado, pois o período em que ficava aberto sobrecarrega o filtro em virtude da vazão ser de 0,279 l/s, com uma perda de carga de $4,23 \times 10^{-2} \mathrm{~m}$. A taxa de filtração após a passagem da água pelo filtro, com a abertura representativa para que a filtração fosse lenta, equivale a uma vazão de $0,012 \mathrm{l} / \mathrm{s}$ e uma perda de carga de $9,08 \times 10^{-6} \mathrm{~m}$, e com o registro completamente aberto a vazão de filtração foi de $0,151 \mathrm{l} / \mathrm{s}$, com uma perda de carga de $9,17 \times 10^{-4} \mathrm{~m}$.

Para garantir que houvesse uma redução mais satisfatória dos parâmetros analisados, decidiu-se, na terceira carreira de filtração, adicionar uma camada de carvão ativado granular ao leito filtrante (Figura 13). O carvão ativado é geralmente utilizado para retirar da água impurezas dissolvidas que, mesmo em pequenas proporções, podem causar odor, gosto e coloração. Outra função para o carvão ativado é retirar os compostos fenólicos que podem implicar na qualidade final do fluído. 
Figura 13 - Camada de carvão ativado

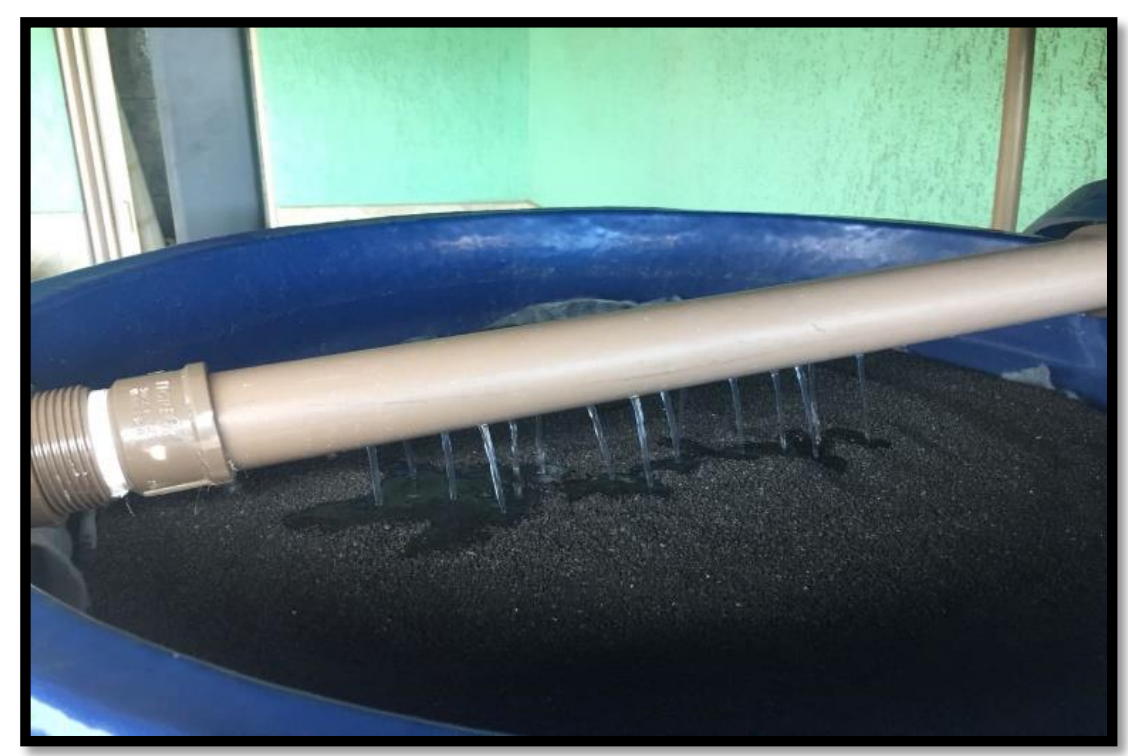

Fonte: Autor

Por meio de ensaios, o carvão ativado utilizado no trabalho possuía granulometria de 2,4 $\mathrm{mm}$ e, inicialmente, foi adicionado ao filtro com uma camada de $7 \mathrm{~cm}$ de espessura, porém, com essa espessura de camada, o ganho de carga no filtro foi elevada, o que levaria o mesmo a extravasar em curto período de tempo. Assim, retirou-se toda a camada e foi posta uma nova camada de carvão, reduzida para $4 \mathrm{~cm}$. Cabe destacar que, entre a camada de areia e a camada de carvão ativado, foi adicionado também uma nova manta sintética para auxiliar na remoção de partículas e separar as camadas, a fim de facilitar o procedimento de limpeza do leito filtrante após algumas carreiras de filtração.

Durante a realização da terceira carreira de filtração, percebeu-se que inicialmente a velocidade de filtração estava elevada, causando maior acúmulo de sólidos suspensos sobre o leito filtrante, porém após a passagem de uma menor quantidade de água, com a velocidade de filtração normalizada, observou-se uma melhor qualidade da água. A tabela 11 mostra os resultados dos parâmetros analisados nessa etapa do trabalho. 
Tabela 11 - Terceira carreira de filtração: filtro com seixos, manta sintética, areia, manta sintética e carvão ativado

\begin{tabular}{|c|c|c|}
\hline Parâmetros & Água Bruta & Água tratada \\
\hline DBO & $595,08 \mathrm{mg} / \mathrm{L}$ & $327,18 \mathrm{mg} / \mathrm{L}$ \\
\hline Cor & $886 \mathrm{Pt} / \mathrm{Co}(\mathrm{mgPt} / \mathrm{L})$ & $712 \mathrm{Pt} / \mathrm{Co}(\mathrm{mgPt} / \mathrm{L})$ \\
\hline Turbidez & $505 \mathrm{UNT}$ & $393 \mathrm{UNT}$ \\
\hline $\mathrm{pH}$ & 7,60 & 6,99 \\
\hline Cloro Residual Livre & $0,96 \mathrm{mg} / \mathrm{L}$ & $1,15 \mathrm{mg} / \mathrm{L}$ \\
\hline Coliformes Totais & Presença em $100 \mathrm{~mL}$ & Presença em $100 \mathrm{~mL}$ \\
\hline Coliformes Termotolerantes & Presença em $100 \mathrm{~mL}$ & Presença em $100 \mathrm{~mL}$ \\
\hline \multicolumn{2}{|l}{} \\
Legenda: \\
UNT: Unidade Nefelométrica de Turbidez
\end{tabular}

Fonte: Autor

Pela Tabela 11 pode ser observado que o valor da DBO na água tratada está muito acima do esperado, indicando um efluente correspondente a esgoto doméstico bruto. Esse resultado indica que, provavelmente, houve um erro na determinação do parâmetro, pois conforme pode ser observado na Tabela 9, o sistema de tratamento tinha se revelado com boa remoção de DBO, alcançando uma eficiência de $99 \%$.

Para a cor, pode-se considerar que o sistema de tratamento proposto em nenhum momento conseguiu reduzir eficientemente o valor desse parâmetro para a indicação recomentada na Resolução CONAMA № 357/2005, que é abaixo de 75 mgPt/L para águas destinadas ao reuso. O resultado mostrado nas Tabelas 9 e 10, mesmo que elevados, vai ao encontro do que é relatado pela literatura técnica para o parâmetro cor, quando se utiliza apenas unidades de filtração (areia e seixos), haja vista que esse tipo de tratamento não remove eficientemente afluentes com quantidade elevada de cor (DI BERNARDO, 2011). Entretanto, ao adicionar uma camada de carvão ativado durante a realização da terceira carreira de filtração, esperava-se uma redução acentuada desse parâmetro, o que não aconteceu. Tangerino et al. (2006) relatam que o carvão é eficiente na remoção de substâncias que conferem cor à água. Logo, a exemplo do que ocorreu com o parâmetro DBO, pode ter havido falha na determinação desse parâmetro.

Em relação à turbidez, houve uma redução de $22 \%$ desse parâmetro, quando adicionada a camada de carvão. Esse resultado é superior aos valores conseguidos na primeira 
e na segunda carreira de filtração. Contudo, em nenhuma carreira a turbidez ficou abaixo de 100 UNT, como recomendado pela Resolução CONAMA № 357/2005 para água de reuso.

A possibilidade de que os valores mostrados pela Tabela 11 estão comprometidos foi corroborado pelos resultados de coliformes totais e termotolerantes, que indicaram a presença de ambos no efluente tratado. Isso é bastante controverso, pois o resultado de cloro residual livre foi de $1,15 \mathrm{mg} / \mathrm{L}$, então, como pode ser isso possível? Pois não há relatos na literatura técnica de que os coliformes possam ser tão resistentes à presença de uma concentração elevada de cloro livre (575\% acima do valor mínimo recomendado pela Portaria de Consolidação № 5, de 28 de setembro de 2017, para deixar uma rede de distribuição de água livre de coliformes, sendo esse valor de $0,2 \mathrm{mg} / \mathrm{L}$ de cloro residual livre).

\subsection{CUSTO DE IMPLANTAÇÃO DA ETA-PILOTO}

Os valores gastos na implantação da ETA-piloto (Tabela 12) foram referentes à estrutura metálica, mão de obra para instalação do sistema e materiais utilizados. O custo com a realização das análises de água no laboratório contratado não foi computado.

Tabela 12 - Custo de implantação da ETA-piloto

\begin{tabular}{|l|c|}
\hline \multicolumn{1}{|c|}{ Itens } & Valor \\
\hline Estrutura metálica & $\mathrm{R} \$ 2.000,00$ \\
\hline Mão de obra da estrutura & $\mathrm{R} \$ 350,00$ \\
\hline Mão de obra da instalação elétrica & $\mathrm{R} \$ 150,00$ \\
\hline Materiais & $\mathrm{R} \$ 1.666,49$ \\
\hline $\begin{array}{l}\text { Meio filtrante (seixos, areia, carvão ativado e } \\
\text { manta geotêxtil) }\end{array}$ & $\mathrm{R}$ 683,51 \\
\hline Outros & $\mathrm{R}$ 120,00 \\
\hline Total & $\mathrm{R}$ 4.970,00 \\
\hline
\end{tabular}

Fonte: Autor

O item referente aos materiais corresponde às tubulações, conexões, registros, válvulas, caixas d'água e uma bomba d'água de $1 \mathrm{HP}$.

Conforme já mencionado, logo no início da operação da ETA-piloto, foi possível perceber que a estrutura poderia ser reduzida, o que resultaria em um custo de implantação menor ao que foi gasto na estação utilizada neste trabalho. Dessa forma, o valor total 
mostrado na Tabela 12 não é definitivo, havendo, portanto, necessidade de estudo adicional, a fim de se estabelecer um valor mais acessível a um maior número de pessoas.

\subsection{PROPOSTA DE MODELO PARA UMA UNIDADE DE TRATAMENTO PARA ÁGUA DE REUSO}

A alteração da ETA-piloto utilizada neste trabalho para um modelo mais compacto também foi objeto deste trabalho, mas apenas como uma nova proposta, a qual precisará ser validada por outra pesquisa. Esse novo modelo de ETA-piloto proposto (Figura 14), foi resultado do estudo feito durante a elaboração da revisão bibliográfica deste trabalho, bem como pela operação da estrutura mostrada nas Figuras 7 e 9.

Figura 14 - Modelo de ETA-piloto proposto para água de reuso
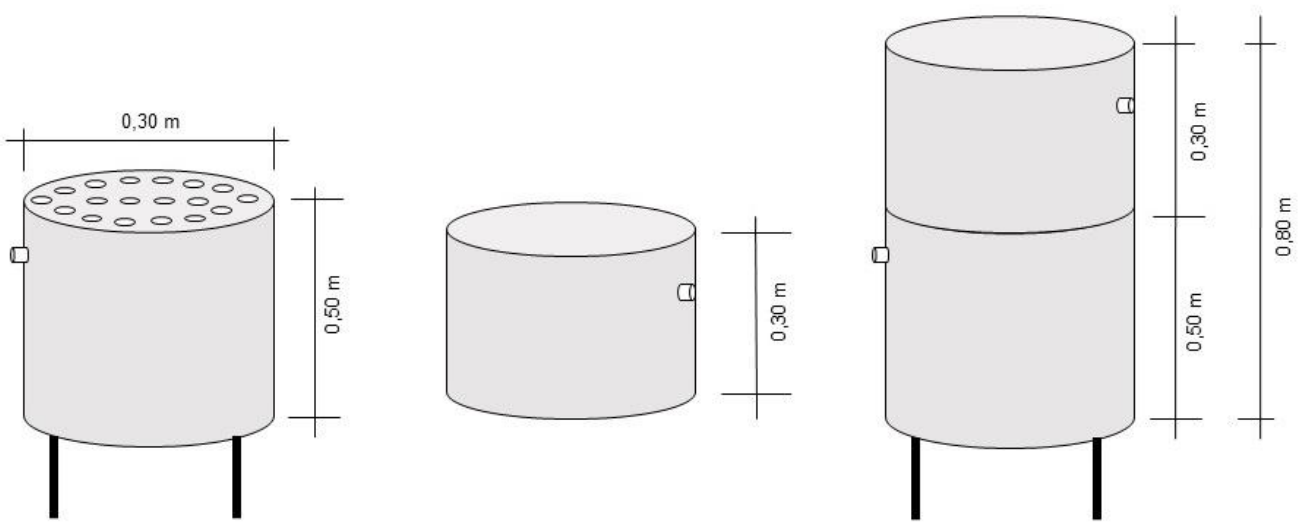

Fonte: Autor

Dentre os trabalhos pesquisados, o estudo desenvolvido por Kishino et al. (1996), que estudaram o tratamento da água de reuso com biorreatores de membranas, foi o que mais serviu de embasamento para o sistema de tratamento mostrado pela Figura 14.

Em linha gerais, o sistema poderá funcionar da seguinte forma: a água oriunda da máquina e do tanque será conduzida para o compartimento inferior. Nesse local a água ficará armazenada por um determinado período de tempo, razão pela qual o primeiro compartimento atuará como um reator, a exemplo do que acontece em um reator anaeróbio, uma vez que o material presente no afluente começará se decompor (reação anaeróbia). O segundo compartimento (parte superior) será um filtro ascendente. Assim, como a unidade 
será operada por batelada, quando uma nova demanda de água for introduzida, ela elevará o nível do líquido, forçando a passagem da água pelo meio filtrante, sendo distribuída por gravidade para o uso pré-estabelecido. 


\section{CONCLUSÃO}

A reutilização da água cinza gerada nas edificações diminui o consumo de água potável para fins menos nobres e contribui para a sustentabilidade hídrica das cidades, pois, em um país onde o saneamento básico não é para todos e a maioria das cidades despeja o esgoto doméstico diretamente nos rios ou a céu aberto, essa medida minimiza a quantidade de poluição lançada nos corpos hídricos.

O sistema de tratamento de água cinza clara, desenvolvido em escala piloto, contribuiu de forma positiva para o recebimento e armazenamento da água filtrada de dois efluentes domésticos, a máquina de lavar roupa e o tanque da área de serviço. Nesse sistema, quando em pleno funcionamento, a água cinza passava por um filtro com três camadas de agregados (seixos, areia e carvão ativado) e, ao final, o efluente foi utilizado na residência para fins não potáveis, como por exemplo, a lavagem de piso.

Em relação às avaliações da estrutura ETA-piloto deste estudo, as conclusões podem ser sintetizadas da seguinte maneira:

- A ETA-piloto apresentou uma estrutura de grande porte para ser utilizada em residências unifamiliares, sendo assim não é uma estrutura de fácil mobilidade, sendo, portanto, de difícil instalação em residências menores.

- Devido a estrutura robusta, o custo estrutural da ETA-piloto também não foi muito acessível, visto que é necessário conciliar inovações tecnológicas com custo/benefício.

- O sistema ETA-piloto recebia um volume de 250 L por semana, visto que se usava a lavanderia apenas uma vez a cada semana. As águas eram oriundas da máquina de lavar e do tanque. Assim, após o tratamento, o uso do efluente era destinado à lavagem de áreas e garagem; porém, foi observado que a oferta era maior que a demanda, e isso acabava gerando um problema de odor.

- Com a pequena demanda na residência, verificou-se também que os reservatórios de água bruta e de água tratada poderiam ser menores.

- As águas para reuso foram utilizadas apenas na lavagem de áreas e garagem, pois o local em que a ETA-piloto foi instalada era uma residência unifamiliar já pronta, e não era viável a instalação da tubulação para levar está água para outros compartimentos da residência. 
Foram realizadas três análises da água de reuso, correspondente a cada carreira de filtração. Nas duas primeiras análises não foram detectados resultados microbiológicos, porém na última carreira, com o filtro completo (três camadas filtrantes), detectou-se a presença de coliformes totais e termotolerantes. O laboratório responsável pelas análises indicou apenas se houve ausência ou presença dos mesmos, não quantificando a amostra. resultado positivo da presença de coliformes na amostra de água de reuso tratada, durante a terceira carreira de filtração, foi acompanhada da presença de um residual de cloro livre de $1,15 \mathrm{mg} / \mathrm{L}$, o que indica falha desse resultado, uma vez que não há relato na literatura técnica que bactérias do grupo coliformes consigam resistir à quantidade de cloro registrada pelo laboratório. Diante disso, a realização das análises por um terceiro, constituiu uma limitação significativa do trabalho.

Contudo, considerando válidos os resultados encontrados em todas as carreiras de filtração, o efluente da água reuso produzida pode ser utilizada conforme a classe 4 da Resolução CONAMA № 357/2005, a qual determina a utilização dessa classe apenas para a navegação e harmonia paisagística.

Os resultados qualitativos apresentados pela ETA-Piloto, utilizando o sistema de filtração, não foram satisfatórios para reuso em residências, visto que os parâmetros deveriam estar apropriados para as classes 1, 2 e 3 da Resolução CONAMA № 357/2005. Entretanto, os resultados não são definitivos, havendo necessidade de se repetir as carreiras de filtração para fins de confirmação dos valores encontrados, pois a possibilidade de preservar um recurso que tende a ser cada vez mais precioso exige trabalho, vigilância e seriedade. Assim, quando da repetição da pesquisa, recomenda-se que as análises sejam realizadas pelos próprios pesquisadores, a fim de se evitar a interferência de terceiros.

Isso posto, foi possível constatar que mesmo diante equívocos ocorridos em respostas duvidosas, particularmente no que se refere ao aspecto laboratorial, o reuso de água para fins não potáveis em residências pode se tornar uma alternativa tecnológica cada vez mais presente na vida das pessoas, necessitando, contudo, de estudos adicionais para torná-la mais acessível a um maior número de pessoas. 


\section{REFERÊNCIAS}

ALLEN, Lucy; CHRISTIAN-SMITH, Juliet; PALANIAPPAN, Meena. Overview of Greywater Reuse: The Potential of Greywater Systems to Aid Sustainable Water Management. Califórnia, 2010. ALMEIDA, Rodrigo G. Aspectos legais para a água de reuso. Rio de Janeiro: Essentia Editora, 2011.

ALVES, W. C.; KIPERSTOK, A.; ZANELLA, L.; PHILIPPI, L. S.; SANTOS, M. F. L.; VALENTINA, R. S. D.; OLIVEIRA, L.V.; GONÇALVES, R. F. Tecnologias de conservação em sistemas prediais. In: GONÇALVES, R. F. (Coord.). Conservação de água e energia em sistemas prediais e públicos de abastecimento de água. Programa de Pesquisa em Saneamento Básico, Rio de Janeiro: ABES, 2009.

ASSOCIAÇÃO BRASILEIRA DE NORMAS TÉCNICAS NM 248 Agregados - Determinação da composição granulométrica foi a norma utilizada para determinar as granulometrias. Rio de Janeiro, 2001.

BAZZARELLA, B. B. Caracterização e aproveitamento de água cinza para uso não potável em edificações. 2005. 165 f. Dissertação (Mestrado em engenharia Ambiental) - Programa de PósGraduação em Engenharia ambiental, Universidade Federal do Espirito Santo, Vitória.

BRASIL. Ministério do Meio Ambiente. Agência Nacional de Águas; FEDERAÇÃO DAS INDUSTRIAS DOS ESTADOS DE SÃO PAULO; SINDICATO DA INDÚSTRIA DA CONSTRUÇÃO DO ESTADO DE SÃO PAULO. Conservação e reuso de água em edificações. São Paulo, 2005. Disponível em: http://www.gerenciamento.ufba.br Acesso em: Maio de 2018.

CHRISTOVA-BOAL, D.; EDEN, R. E.; MACFARLANE, S. Na investigation into greywater reuse for urban residential proprieties. Desalination, 1996.

CLARKE, R. e KING, J. O atlas da água: O mapeamento completo do recurso mais precioso do planeta. 2005. 1a edição. Editora Puplifolha. São Paulo.

CONAMA № 357/2005 - Classificação dos corpos de água e diretrizes ambientais para o seu enquadramento, bem como estabelece as condições e padrões de lançamento de efluentes, \begin{tabular}{lllll}
\hline $\mathrm{e}$ & dá & outras & providências. & Disponível
\end{tabular} <http://www.mma.gov.br/port/conama/legiabre.cfm?codlegi=459>. Acesso em: 13 maio 2018.

CREDER, Hélio. Instalações Hidráulicas e Sanitárias. 6. Ed. Rio de Janeiro, LTC, 2012.

CUNHA, Vanessa D. Estudo Para Proposta de Critério de Qualidade da Água Para Reuso Urbano.2008. Dissertação (mestrado) - Escola Politécnica da Universidade São Paulo, São Paulo, 2008.

DI BERNARDO, Luiz et al. Tratabilidade de Água e dos resíduos gerados em estações de tratamento de Água. São Paulo: LDiBe, 2011. 
DIXON, A.; BUTLER, D.; FEWKES, A. Water saving potential of domestic water reuse systems using greywater and rainwater in combination. Water Science and Technology, 1999.

EPA - EVIRONMENTAL PROTECTION AGENCY. Manual guidelines for water reuse. Disponível em <www.epa.gov> acesso em: 10 abr. 2018.

ERIKSSON, E.; AUFFARTH, K.; MOGENS, H.; LEDIN, A. A characteristics of grey wastewater. Urban Water, 2002.

ESCALERA, Oscar A. N. Reuso direto das águas reiduárias municipais tratadas: Uma forma de conservação de água e disposição final. Dissertação (mestrado) - Faculdade de Engenharia Civil da Universidade estadual de Campinas para obtenção do título de mestre em Engenharia Civil. Campinas, 1995.

FERREIRA, D. F. Aproveitamento de águas pluviais e reuso de águas cinzas para fins não potáveis em um condomínio residencial localizado em Florianópolis - Sc. 2005. (Graduação em Engenharia civil) Departamento de Engenharia Civil, Universidade Federal de Santa Catarina, Santa Catarina.

FIORI, S. FERNANDES, V. M. C. PIZZO, H. Avaliação qualitativa e quantitativa do reuso de águas cinzas em edificações. 2006. Programa de Pós-Graduação em engenharia na Universidade de Passo Fundo, Rio Grande do Sul.

FUNASA. Manual de Saneamento. Brasília: FUNASA, 2004.

GHISI, E. Potential for potable water savings by using rainwater in the residential sector of Brazil. Artigo submetido à revista Building and Environment, mas ainda não publicado, 2004. GIACCHINI, Margolaine. Uso e reuso da Água. Paraná, 2010. Disponível em <http://venus.maringa.pr.gov.br/residuos/arquivo.php?id=96>. Acesso em: 13 abr. 2018.

GONÇALVES, Ricardo F. Uso Racional da Água em Edificações. Rio de Janeiro, 2006. Disponível em <https://www.finep.gov.br/images/apoio-e-financiamento/...de.../Uso_agua__final.pdf>. Acesso em 24 abr. 2018.

GUNTER, F. Wastewater treatment by greywater separation: Outline for a biologically based greywater purification plant in Sweden. Ecological Engineering, 2000.

HESPANHOL, Ivanildo. Água e Saneamento básico - Uma Visão Realista. Águas Doces do Brasil: Capital Ecológico, Uso e Conservação. Editora Escrituras, 1999.

HILL, S.; BIRKS, R; DIAPER, C.; JEFFREY, P. Na evaluating og single-house greywater recycling system. In: Proc. IWA International Symposium on Wastewater Reclamation \& Reuse, 2003, cidade do México.

IDEC. Instituto Brasileiro de Defesa do Consumidor (2010). Água um recurso cada vez mais ameaçado. Disponível em: https://idec.org.br/ Acesso em: Maio de 2018.

JEFFERSON, et al. Technologies for domestic wastewater recycling. Urban Water, 1999. 
KISHINO, H.; ISHIDA, H.; IWABU, H.; NAKANO. Domestic wastewater reuse using a submerged membrane bioreactor. 1996.

MACHADO, J. 2009. A redescoberta do Aquífero Guarani; Scientifc American Brasil. MARCH, J. G.; GUAL, M.; OROZCO, F. Experiences on greywater re-use for toilet flushing in a hotel (Mallorca Island, Spain). 2004.

MAY, S. Caracterização, tratamento e reuso de águas cinzas e aproveitamento de águas pluviais em edificações. 2009. Tese (Doutorado) - Escola Politécnica da Universidade de São Paulo, São Paulo.

MAY, S.; HESPANHOL, I. Caracterização e Tratamento de Águas Cinzas para consumo não Potável em Edificações. In: CONGRESSO INTERAMERICANO DE INGENIERIA SANITÁRIA Y AMBIENTAL, 30., 2006, Punta Del Leste. Anais... Punta Del Leste: Asociación Interamericana de Ingenieria Ambiental, 2006.

MAY, Simone. Tratamento de águas cinzas claras para reuso não potável em edificações. Dissertação (mestrado) - Universidade de São Paulo para obtenção do título de Mestre em Engenharia. São Paulo, 2004.

MIERZWA, José. O uso racional e o reuso como ferramenta para o gerenciamento de águas e efluentes na indústria estudo de caso da Kodak Brasileira. Tese (doutorado) Escola Politécnica da Universidade de São Paulo. São Paulo, 2002.

NIRENBERG, Larissa P.; REIS, Ricardo P. A. Avaliação do Desempenho de Sistema de Reúso de Água de Uma Edificação Unifamiliar Em Goiânia-Go. Goiânia, 2010. Disponível em < https://www.revistas.ufg.br/reec/article/download/8862/6206>. Acesso em: 04 maio 2018. NOLDE, E. Greywater reuse systems for toilet flushing in multi-storey buildings - over tem years experience in Berlin. Urban Water, 1999.

NSW HEALTH. Greywater reuse in Sewered single domestic premises, Sidney, 2002. Disponível em: http://www.health.nsw.gov.au/. Acesso em: Abril de 2018.

OLIVEIRA, Naiane M.; SILVA, Marcos P.; CARNEIRO, Vandervilson . Reuso da água: um novo paradigma de sustentabilidade. Revista UEG, p 12. Goiania , 2013.

PIDOU, Mark et al. Greywater recycling: treatment options and applications. 2007. Proceedings of the Institution of Civil Engineers. Queensland, 2007.

RABÊLO, Marcelle M. P. S. Caracterização de Águas Cinzas e Negras de Origem Residencial e Análise da Eficiência de Reator Anaeróbio com Chicanas. Dissertação ( mestrado) - Programa de Pós-Graduação em Recursos Hídricos e Saneamento - PPGRHS da Universidade Federal de Alagoas. MACEIÓ, 2011.

RAMPELOTTO, Geraldo. Caracterização e Tratamento de Águas Cinzas Visando Reuso Doméstico. 2014. Dissertação (mestrado) - Pós-Graduação em Engenharia Civil. Santa Maria, 2014. 
RAPOPORT, Beatriz. Águas Cinzas: Caracterização, Avaliação Financeira e Tratamento Para Reuso Domiciliar e Condominial. TCC - Escola Nacional de Saúde Pública. Rio de Janeiro, 2004.

SANTOS, Hiltonn. Critérios de qualidade da água para reuso. Revista DAE- SABESP, 1993. As muitas lutas na baixada Santista, São Paulo, ed no 174, p. 1- 9, nov/dez 1993.

SELLA, M, B. Reuso de águas cinzas: Avaliação da viabilidade da implantação do sistema em residências. 2011. 72 f. Trabalho de Diplomação (Graduação em Engenharia Civil) Departamento de Engenharia Civil, Universidade Federal do Rio Grande do Sul, Porto Alegre.

SERPA, Thiago. Tratamento e Tratamento e Reuso da Água Cinza. Disponível em <https://liter.com.br/tratamento-e-reuso-de-agua-cinza/> acesso em 13/03/2018.

TANGERINO, E.P et al. Remoção de cor em colunas de carvão ativado granular como polimento de efluente de instalação filme, em função da taxa de aplicação.. Montevideo, 2006.

TOMAZ, P. Economia de água para Empresas e Residências. Navegar editora, São Paulo, 2001.

UNESCO. Organizações das Nações Unidas para a Educação, a ciência e a cultura. Disponível em: http://www.unesco.org/new/pt/brasilia/ Acesso em: Abril de 2018.

WESTERHOFF, Garrett. P. Un update of research needs for water reuse. 1984. In: BREGA FILHO, D.; MANCUSO, P.C.S. Capítulo 2 - Conceito de reúso de água. In: REÚSO DE ÁGUA. Barueri, 2003. 


\section{ANEXO I - MEMORIAL DE CÁLCULO}

Memorial de cálculo para vazão (Q), perda de carga (hf) e número de Reynolds.

V= volume

$\mathrm{t}=$ tempo

$\mathrm{D}=$ diâmetro

$A=$ área

$\mathrm{L}=$ comprimento

k= rugosidade

$\checkmark=$ Viscosidade cinemática do fluido

- Cálculo da bomba para o reservatório de água bruta 2, trecho (R1 para R2):

Dados:

$\mathrm{V}=1 \mathrm{~L}$

$\mathrm{t}=1,8 \mathrm{~s}$

$\mathrm{D}=32 \mathrm{~mm}$

$v=10^{-6}$

$k=0,06$

$\mathrm{L}=2,35 \mathrm{~m}$

$Q=\frac{\mathrm{V}}{t}=\frac{1}{1,8}=0,55 \quad \Rightarrow \quad Q=5,55 \times 10^{-4} \frac{\mathrm{m}^{3}}{\mathrm{~s}}$

$A=\frac{\pi * D^{2}}{4}=\frac{\pi * 0,032^{2}}{4} \quad \Rightarrow \quad A=8,04 \times 10^{-4} \mathrm{~m}^{2}$

Vméd $=\frac{Q}{A}=\frac{5,55 \times 10^{-4}}{8,04 \times 10^{-4}} \quad \Rightarrow \quad$ Vméd $=6,91 \times 10^{-1} \frac{\mathrm{m}}{\mathrm{s}}$

$N^{\mathrm{o}} \operatorname{Re}$ ynolds $=\frac{\text { Vméd } * D}{v}=\frac{6,91 \times 10^{-1} * 0,032}{10^{-6}} \Rightarrow N^{\mathrm{o}} \operatorname{Re}$ ynolds $=22104,85$

$\frac{k}{D}=\frac{0,06}{32} \quad \Rightarrow \quad \frac{k}{D}=0,001875$

Conforme ábaco de moody (Anexo II) o valor de $f=0,031$

$h f=f \frac{L * V m e ́ d^{2}}{D * 2 g}=0,031 \frac{2,35 *\left(6,91 \times 10^{-1}\right)^{2}}{0,032 * 2 * 9,8} \quad \Rightarrow \quad h f=0,055 \mathrm{~m}$ 
Conforme a tabela de Hélio Creder para PVC (Anexo III), as perdas de carga localizada no trecho (R1 para R2) correspondem a:

\begin{tabular}{|c|c|}
\hline Conexões & k \\
\hline 1 Registro de gaveta (aço) & 0,2 \\
\hline 1 Joelho de 45o & 1 \\
\hline 1 Joelho de 90 & 2 \\
\hline
\end{tabular}

$\frac{\text { Vméd }^{2}}{2 \mathrm{~g}}=\frac{6,91 \times 10^{-1}}{2 * 9,8} \quad \Rightarrow \frac{\text { Vméd }^{2}}{2 \mathrm{~g}}=0,024 \mathrm{~m}$

1 Registro de gaveta $\rightarrow h f 1=\frac{\text { Vméd }^{2}}{2 g} * k=0,024 * 0,2 \quad \Rightarrow \quad h f 1=4,86 \times 10^{-3} \mathrm{~m}$ 1 Joelho de 45ㅇ $\rightarrow h f 2=\frac{\text { Vméd }^{2}}{2 g} * k=0,024 * 1 \quad \Rightarrow \quad h f 2=2,13 \times 10^{-2} \mathrm{~m}$ 1 Joelho de 90 o $\rightarrow$ hf $3=\frac{\text { Vméd }^{2}}{2 g} * k=0,024 * 2 \quad \Rightarrow \quad h f 3=4,86 \times 10^{-2}$ hftotal $=\mathrm{hf}+\mathrm{hf} 1+\mathrm{hf} 2+\mathrm{hf} 3 \quad \Rightarrow \quad$ hftotal $=1,33 \times 10^{-1} \mathrm{~m}$ - Cálculo do reservatório de água bruta 2 com registro pouco aberto para filtro:

Dados:

$V=0,8 \mathrm{~L}$

$t=60 s$

$\mathrm{D}=50 \mathrm{~mm}$

$v=10^{-6}$

$k=0,06$

$\mathrm{L}=0,75 \mathrm{~m}$

$Q=\frac{\mathrm{V}}{t}=\frac{0,8}{60}=0,0133 \quad \Rightarrow \quad Q=1,33 \times 10^{-5} \frac{\mathrm{m}^{3}}{\mathrm{~s}}$

$A=\frac{\pi * D^{2}}{4}=\frac{\pi * 0,050^{2}}{4} \quad \Rightarrow \quad A=1,96 \times 10^{-3} \mathrm{~m}^{2}$

Vméd $=\frac{Q}{A}=\frac{1,33 \times 10^{-5}}{1,96 \times 10^{-3}} \quad \Rightarrow \quad$ Vméd $=6,79 \times 10^{-3} \frac{\mathrm{m}}{\mathrm{s}}$

$N^{\mathrm{o}} \operatorname{Re}$ ynolds $=\frac{\text { Vméd } * D}{v}=\frac{6,79 \times 10^{-3} * 0,050}{10^{-6}} \Rightarrow N^{\mathrm{o}} \operatorname{Re}$ ynolds $=339,5$ 
$\frac{k}{D}=\frac{0,06}{50} \quad \Rightarrow \quad \frac{k}{D}=0,0012$

Conforme ábaco de moody (Anexo II) o valor de $f=0,19$

$h f=f \frac{L * \text { Vméd }^{2}}{D * 2 g}=0,19 \frac{0,75 *\left(6,79 \times 10^{-3}\right)^{2}}{0,050 * 2 * 9,8} \quad \Rightarrow \quad h f=6,65 \times 10^{-6} \mathrm{~m}$

Conforme a tabela de Hélio Creder para PVC (Anexo III), as perdas de carga localizada no trecho reservatório 2 para filtro correspondem a:

\begin{tabular}{|c|c|}
\hline Conexões & k \\
\hline 1 Registro de gaveta & 37,9 \\
\hline 2 joelhos de 90 & 1,3 \\
\hline
\end{tabular}

$\frac{\text { Vméd }}{2}=\frac{6,79 \times 10^{-3}}{2 * 9,8} \quad \Rightarrow \quad \frac{\text { Vméd }^{2}}{2 \mathrm{~g}}=3,46 \times 10^{-4} \mathrm{~m}$

1 Registro de gaveta $\rightarrow h f 1=\frac{\text { Vméd }^{2}}{2 g} * k=6,79 \times 10^{-3} * 37,9 \quad \Rightarrow \quad h f 1=1,31 \times 10^{-2} \mathrm{~m}$

2 Joelho de 90 o $\rightarrow h f 2=\frac{\text { Vméd }^{2}}{2 g} * k=6,79 \times 10^{-3} * 1,3 \quad \Rightarrow h f 2=9,01 \times 10^{-4} \mathrm{~m}$

hftotal $=$ hf + hf $1+$ hf $2 \quad \Rightarrow$ hftotal $=1,40 \times 10^{-2} \mathrm{~m}$

- Cálculo do reservatório de água bruta 2 com registro totalmente aberto para filtro:

Dados:

$V=3,35 \mathrm{~L}$

$\mathrm{t}=12 \mathrm{~s}$

$\mathrm{D}=50 \mathrm{~mm}$

$v=10^{-6}$

$k=0,06$

$\mathrm{L}=0,75 \mathrm{~m}$

$Q=\frac{\mathrm{V}}{t}=\frac{3,35}{12}=0,279 \quad \Rightarrow \quad Q=2,79 \times 10^{-4} \frac{\mathrm{m}^{3}}{\mathrm{~s}}$ 
$A=\frac{\pi * D^{2}}{4}=\frac{\pi * 0,050^{2}}{4} \quad \Rightarrow \quad A=1,96 \times 10^{-3} \mathrm{~m}^{2}$

Vméd $=\frac{Q}{A}=\frac{2,79 \times 10^{-4}}{1,96 \times 10^{-3}} \quad \Rightarrow \quad$ Vméd $=1,42 \times 10^{-1} \frac{\mathrm{m}}{\mathrm{s}}$

$N^{\mathrm{o}} \operatorname{Re} y$ nolds $=\frac{\text { Vméd } * D}{v}=\frac{1,42 \times 10^{-1} * 0,050}{10^{-6}} \Rightarrow N^{\mathrm{o}} \operatorname{Re}$ ynolds $=7108,9$

$\frac{k}{D}=\frac{0,06}{50} \quad \Rightarrow \quad \frac{k}{D}=0,0012$

Conforme ábaco de moody (Anexo II) o valor de $\mathrm{f}=0,035$

$h f=f \frac{L * \text { Vméd }^{2}}{D * 2 g}=0,035 \frac{0,75 *\left(1,42 \times 10^{-1}\right)^{2}}{0,050 * 2 * 9,8} \quad \Rightarrow \quad h f=5,41 \times 10^{-4} \mathrm{~m}$

Conforme a tabela de Hélio Creder para PVC (Anexo III), as perdas de carga localizada no trecho reservatório 2 para filtro correspondem a:

\begin{tabular}{|c|c|}
\hline Conexões & k \\
\hline 1 Registro de gaveta & 37,9 \\
\hline 2 joelhos de 90 & 1,3 \\
\hline
\end{tabular}

$\frac{\text { Vméd }^{2}}{2 \mathrm{~g}}=\frac{\left(4,42 \times 10^{-1}\right)^{2}}{2 * 9,8} \quad \Rightarrow \quad \frac{\text { Vméd }^{2}}{2 \mathrm{~g}}=3,91 \times 10^{-2} \mathrm{~m}$

1 Registro de gaveta $\rightarrow h f 1=\frac{\text { Vméd }^{2}}{2 g} * k=3,91 \times 10^{-2} * 37,9 \quad \Rightarrow \quad h f 1=2,68 \times 10^{-3} \mathrm{~m}$

2 Joelho de 90 o $\rightarrow h f 2=\frac{\text { Vméd }^{2}}{2 g} * k=3,91 \times 10^{-2} * 1,3 \quad \Rightarrow h f 2=3,91 \times 10^{-2} m$

hftotal $=\mathrm{hf}+\mathrm{hf} 1+\mathrm{hf} 2 \quad \Rightarrow$ hftotal $=4,23 \times 10^{-2} \mathrm{~m}$

- Cálculo do filtro com registro pouco aberto para reservatório de água tratada:

Dados:

$\mathrm{V}=1 \mathrm{~L}$

$\mathrm{t}=83 \mathrm{~s}$

$\mathrm{D}=50 \mathrm{~mm}$

$v=10^{-6}$ 
$k=0,06$

$\mathrm{L}=0,51 \mathrm{~m}$

$$
\begin{array}{lll}
Q=\frac{\mathrm{V}}{t}=\frac{1}{83}=0,012 & \Rightarrow & Q=1,20 \times 10^{-5} \frac{\mathrm{m}^{3}}{\mathrm{~s}} \\
A=\frac{\pi * D^{2}}{4}=\frac{\pi * 0,050^{2}}{4} & \Rightarrow & A=1,96 \times 10^{-3} \mathrm{~m}^{2}
\end{array}
$$

$$
\text { Vméd }=\frac{Q}{A}=\frac{1,20 \times 10^{-5}}{1,96 \times 10^{-3}} \quad \Rightarrow \quad \text { Vméd }=6,14 \times 10^{-3} \frac{\mathrm{m}}{\mathrm{s}}
$$

$N^{\mathrm{o}} \operatorname{Re} y$ nolds $=\frac{\text { Vméd } * D}{v}=\frac{6,14 \times 10^{-3} * 0,050}{10^{-6}} \Rightarrow N^{\mathrm{o}} \operatorname{Re}$ ynolds $=306,8$

$\frac{k}{D}=\frac{0,06}{50} \quad \Rightarrow \quad \frac{k}{D}=0,0012$

Conforme ábaco de moody (Anexo II) o valor de $\mathrm{f}=0,208$

$$
h f=f \frac{L * \text { Vméd }^{2}}{D * 2 g}=0,208 \frac{0,51 *\left(6,14 \times 10^{-3}\right)^{2}}{0,050 * 2 * 9,8} \quad \Rightarrow \quad h f=4,09 \times 10^{-6} \mathrm{~m}
$$

Conforme a tabela de Hélio Creder para PVC (Anexo III), as perdas de carga localizada no trecho filtro para reservatório de água tratada correspondem a:

\begin{tabular}{|c|c|}
\hline Conexões & $\mathbf{k}$ \\
\hline 2 joelhos de 90ㅇ & 1,3 \\
\hline
\end{tabular}

$\frac{\text { Vméd }^{2}}{2 \mathrm{~g}}=\frac{\left(6,14 \times 10^{-3}\right)^{2}}{2 * 9,8} \quad \Rightarrow \quad \frac{\text { Vméd }^{2}}{2 \mathrm{~g}}=1,92 \times 10^{-6} \mathrm{~m}$

2 Joelho de 90 o $\rightarrow h f 1=\frac{\text { Vméd }^{2}}{2 g} * k=1,92 \times 10^{-6} * 1,3 \quad \Rightarrow h f 1=4,99 \times 10^{-6} m$

$$
\text { hftotal }=\mathrm{hf}+\mathrm{hf} 1 \quad \Rightarrow \text { hftotal }=9,08 \times 10^{-6} \mathrm{~m}
$$

- Cálculo do filtro com registro totalmente aberto para reservatório de água tratada:

Dados:

$\mathrm{V}=1 \mathrm{~L}$

$t=6,62 s$

$D=50 \mathrm{~mm}$ 
$v=10^{-6}$

$k=0,06$

$\mathrm{L}=0,51 \mathrm{~m}$

$Q=\frac{\mathrm{V}}{t}=\frac{1}{6,62}=0,15 \quad \Rightarrow \quad Q=1,51 \times 10^{-4} \frac{m^{3}}{s}$

$A=\frac{\pi * D^{2}}{4}=\frac{\pi * 0,050^{2}}{4} \quad \Rightarrow \quad A=1,96 \times 10^{-3} \mathrm{~m}^{2}$

Vméd $=\frac{Q}{A}=\frac{1,51 \times 10^{-4}}{1,96 \times 10^{-3}} \quad \Rightarrow \quad$ Vméd $=7,69 \times 10^{-2} \frac{\mathrm{m}}{\mathrm{s}}$

$N^{\mathrm{o}} \operatorname{Re} y$ nold $s=\frac{\text { Vméd } * D}{v}=\frac{7,69 \times 10^{-2} * 0,050}{10^{-6}} \Rightarrow N^{\mathrm{o}} \operatorname{Re} y$ nold $s=3846,6$

$\frac{k}{D}=\frac{0,06}{50} \quad \Rightarrow \quad \frac{k}{D}=0,0012$

Conforme ábaco de moody (Anexo II) o valor de $f=0,043$

$h f=f \frac{L * \text { Vméd }^{2}}{D * 2 g}=0,043 \frac{0,51 *\left(7,69 \times 10^{-2}\right)^{2}}{0,050 * 2 * 9,8} \quad \Rightarrow \quad h f=1,32 \times 10^{-4} \mathrm{~m}$

Conforme a tabela de Hélio Creder para PVC (Anexo III), as perdas de carga localizada no trecho filtro para reservatório de água tratada correspondem a:

\begin{tabular}{|c|c|}
\hline Conexões & $\mathbf{k}$ \\
\hline 2 joelhos de 90 o & 1,3 \\
\hline
\end{tabular}

$\frac{\text { Vméd }^{2}}{2 \mathrm{~g}}=\frac{\left(7,69 \times 10^{-2}\right)^{2}}{2 * 9,8} \quad \Rightarrow \quad \frac{\text { Vméd }^{2}}{2 \mathrm{~g}}=3,02 \times 10^{-4} \mathrm{~m}$

2 Joelho de $900 \rightarrow h f 1=\frac{\text { Vméd }^{2}}{2 g} * k=3,02 \times 10^{-4} * 1,3 \quad \Rightarrow h f 1=7,85 \times 10^{-4} \mathrm{~m}$
hftotal $=\mathrm{hf}+\mathrm{hf} 1$
$\Rightarrow$ hftotal $=9,17 \times 10^{-4} \mathrm{~m}$

- Cálculo da saída do reservatório para distribuição:

Dados:

$V=1 \mathrm{~L}$

$\mathrm{t}=12,21 \mathrm{~s}$ 
$D=25 \mathrm{~mm}$

$V=10^{-6}$

$k=0,06$

$\mathrm{L}=0,57 \mathrm{~m}$

$Q=\frac{\mathrm{V}}{t}=\frac{1}{12,21}=0,082$

$\Rightarrow \quad Q=8,19 \times 10^{-5} \frac{m^{3}}{s}$

$A=\frac{\pi * D^{2}}{4}=\frac{\pi * 0,025^{2}}{4} \quad \Rightarrow \quad A=4,9 \times 10^{-4} \mathrm{~m}^{2}$

Vméd $=\frac{Q}{A}=\frac{8,19 \times 10^{-5}}{4,9 \times 10^{-4}} \quad \Rightarrow \quad$ Vméd $=1,67 \times 10^{-2} \frac{\mathrm{m}}{\mathrm{s}}$

$N^{\mathrm{o}} \operatorname{Re} y$ nold $s=\frac{\text { Vméd } * D}{v}=\frac{1,67 \times 10^{-2} * 0,025}{10^{-6}} \quad \Rightarrow \quad N^{\mathrm{o}} \operatorname{Re}$ ynolds $=4171,1$

$\frac{k}{D}=\frac{0,06}{25} \quad \Rightarrow \quad \frac{k}{D}=0,0024$

Conforme ábaco de moody (Anexo II) o valor de $\mathrm{f}=0,042$

$h f=f \frac{L * \text { Vméd }^{2}}{D * 2 g}=0,042 \frac{0,57 *\left(1,67 \times 10^{-2}\right)^{2}}{0,025 * 2 * 9,8} \quad \Rightarrow \quad h f=1,36 \times 10^{-3} \mathrm{~m}$

Conforme a tabela de Hélio Creder para PVC (Anexo III), as perdas de carga localizada no trecho filtro para reservatório de água tratada correspondem a:

\begin{tabular}{|c|c|}
\hline Conexões & $\mathbf{k}$ \\
\hline 2 joelhos de $90 \mathrm{o}$ & 1,5 \\
\hline
\end{tabular}

$\frac{\text { Vméd }^{2}}{2 \mathrm{~g}}=\frac{\left(1,67 \times 10^{-2}\right)^{2}}{2 * 9,8} \quad \Rightarrow \quad \frac{\text { Vméd }^{2}}{2 \mathrm{~g}}=1,42 \times 10^{-3} \mathrm{~m}$

2 Joelho de 90 $\rightarrow h f 1=\frac{\text { Vméd }^{2}}{2 g} * k=1,42 \times 10^{-3} * 1,5 \quad \Rightarrow h f 1=4,26 \times 10^{-3} \mathrm{~m}$

hftotal $=\mathrm{hf}+\mathrm{hf} 1 \quad \Rightarrow$ hftotal $=5,62 \times 10^{-3} \mathrm{~m}$ 


\section{ANEXO II - ÁBACO DE MOODY}

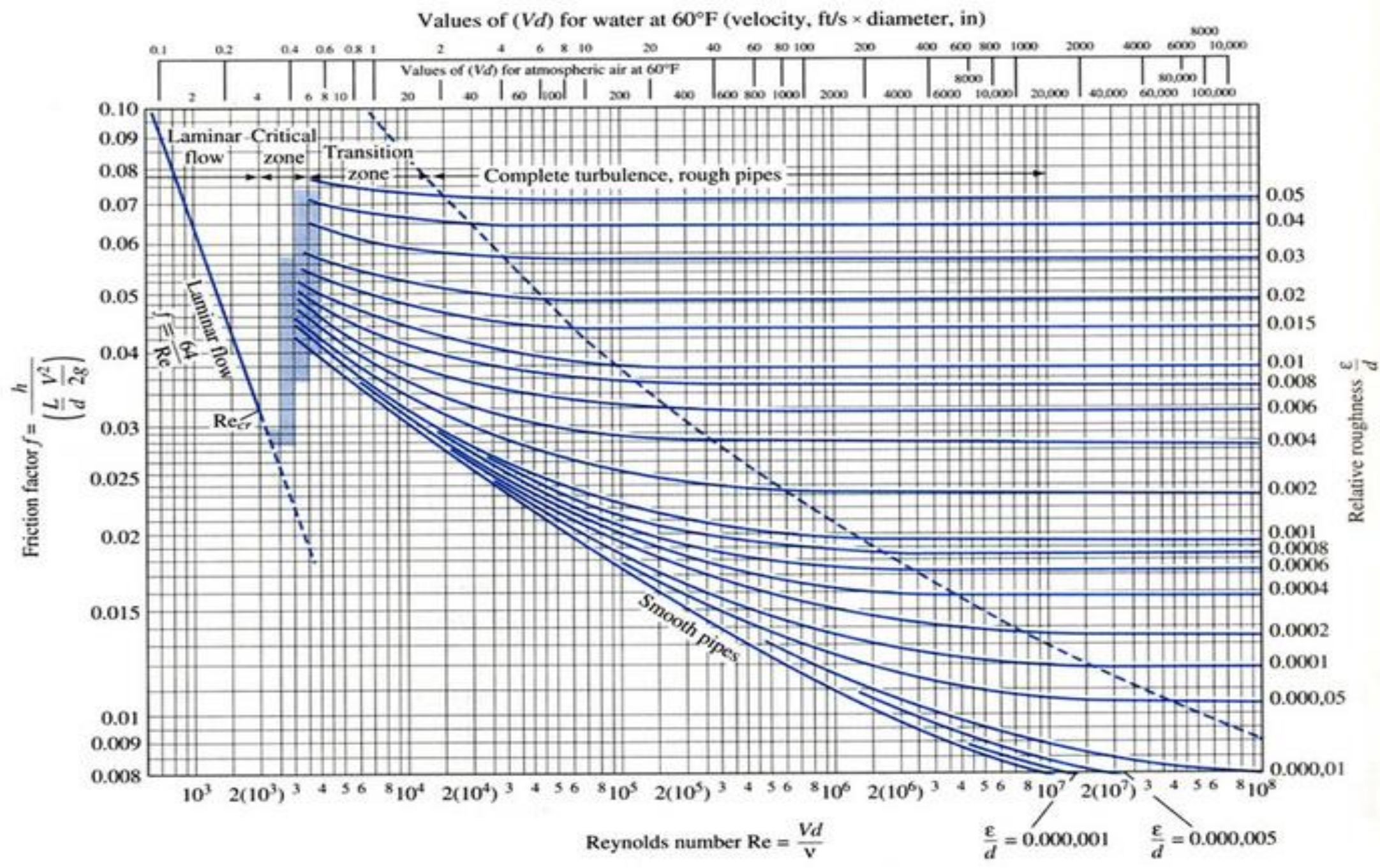




\section{ANEXO III - TABELA PERDA DE CARGAS LOCALIZADAS}

\begin{tabular}{|c|c|c|c|c|c|c|c|c|c|c|c|c|c|c|c|c|c|}
\hline \multirow{2}{*}{\multicolumn{2}{|c|}{$\begin{array}{l}\text { Diametro } \\
\text { nominal }\end{array}$}} & \multirow{3}{*}{$\begin{array}{l}\text { Joekho } \\
90^{\circ}\end{array}$} & \multirow{3}{*}{$\begin{array}{l}\text { Joeho } \\
45^{\circ}\end{array}$} & \multirow{3}{*}{$\begin{array}{l}\text { Curva } \\
90^{\circ}\end{array}$} & \multirow{3}{*}{$\begin{array}{c}\text { Curva } \\
45^{\circ} \\
8\end{array}$} & \multirow{3}{*}{$\begin{array}{c}\text { To } 00 \\
\text { passag } \\
\text { direta }\end{array}$} & \multirow{3}{*}{$\begin{array}{l}\text { Te 90" } \\
\text { saida } \\
\text { de lado }\end{array}$} & \multirow{3}{*}{$\begin{array}{c}\text { Te 90" } \\
\text { saida } \\
\text { blat. }\end{array}$} & \multirow{3}{*}{$\begin{array}{l}\text { Entrada } \\
\text { normal }\end{array}$} & \multirow{3}{*}{ 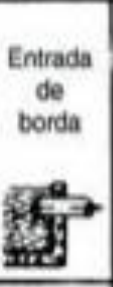 } & \multirow{3}{*}{ 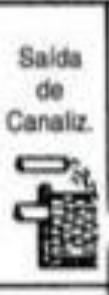 } & \multirow{3}{*}{$\begin{array}{c}\text { valvula } \\
\text { do pee } \\
\text { crivo } \\
\square\end{array}$} & \multicolumn{2}{|c|}{ Vaiv. de retenclio } & \multirow{3}{*}{ Aepintro } & \multirow{3}{*}{ Alogitso } & \multirow{3}{*}{ Aegitson } \\
\hline & & & & & & & & & & & & & \multirow{2}{*}{700} & \multirow{2}{*}{ דenoso } & & & \\
\hline DN & $\frac{(\text { Ret) }}{(-)}$ & & & & & & & & & & & & & & & & \\
\hline 15 & (1/2) & 1,1 & 0,4 & 0,4 & 0,2 & 0,7 & 2,3 & 2.3 & 0,3 & 0,9 & 0.8 & 8,1 & 2.5 & 3.6 & 11,1 & 0.1 & 5.9 \\
\hline 20 & (3/4) & 1.2 & 0.5 & 0.5 & 0,3 & 0.8 & 2,4 & 2.4 & 0.4 & 1.0 & 0.9 & 9.5 & 2.7 & 4,1 & 11,4 & 0.2 & 6.1 \\
\hline 25 & (1) & 1,5 & 0.7 & 0.6 & 0,4 & 0.9 & 3,1 & 3,1 & 0.5 & 1.2 & 1,3 & 13.3 & 3.8 & 5,8 & 15.0 & 0.3 & 8.4 \\
\hline 32 & $(1,1 / 4)$ & 2.0 & 1,0 & 0,7 & 0.5 & 1,5 & 4.6 & 4.5 & 0,6 & 1,8 & 1,4 & 15,5 & 4.9 & 7,4 & 22,0 & 0.4 & 10.5 \\
\hline 40 & $(1,1 / 2)$ & 32 & 1,3 & 1,2 & 0.6 & 2,2 & 7,3 & 7,3 & 1,0 & 2.3 & 3.2 & 18,3 & 6.8 & 2.1 & 35,8 & 0.7 & 17.0 \\
\hline 50 & (2) & 3,4 & 1.5 & 1,3 & 0.7 & 2.3 & 7,6 & 7,6 & 1.5 & 2,8 & 3.3 & 23.7 & 7,1 & 10.8 & 37,9 & 0.8 & 18.5 \\
\hline 60 & $(2,1 / 2)$ & 3,7 & 1.7 & 1,4 & 0,8 & 2,4 & 7,8 & 7,8 & 1,6 & 3,3 & 3,5 & 25,0 & 8.2 & 12.5 & 38,0 & 0,9 & 19.0 \\
\hline 75 & (3) & 3.9 & 1.8 & 1.5 & 0.9 & 2.5 & 8,0 & 8.0 & 2.0 & 3,7 & 3.7 & 26.8 & 9.3 & 14.2 & 40.0 & 0.9 & 20.0 \\
\hline 100 & (4) & 4,3 & 1,9 & 1,6 & 1,0 & 2.6 & 8,3 & 8.3 & 2.2 & 4,0 & 39 & 28.6 & 10,4 & 16,0 & 42,3 & 1.0 & 22,1 \\
\hline 125 & (5) & 4,9 & 2.4 & 1,9 & 1,1 & 3.3 & 10.0 & 10.0 & 2.5 & 5,0 & 4.9 & 37,4 & 12.5 & 19.2 & 50,9 & 1,1 & 26.2 \\
\hline 150 & (6) & 5,4 & 2.6 & 2,1 & 1,2 & 3,8 & 11,1 & 11,1 & 2.8 & 5,6 & 5.5 & 43,4 & 13,9 & 21,4 & 56,7 & 12 & 28,9 \\
\hline
\end{tabular}

Fig. 1.16 (d) Perdas de cargas localizadas - sua equivalência em metros de tubulação de PVC rígido ou cobre.

Fonte: Instalações Prediais de Água Potável - Hélio Creder 6ạ ed. Pag. 